\title{
Com o diabo no corpo: os terríveis papagaios do Brasil colônia
}

\section{Dante Martins Teixeira ${ }^{1}$}

RESUMO: Desde a Antiguidade, papagaios, periquitos e afins (Psittacidae) fascinaram os europeus por seu vivo colorido e uma notável capacidade de interação com seres humanos. A descoberta do Novo Mundo nada faria além de acrescentar novos elementos ao tráfico de animais exóticos há muito estabelecido pelos europeus com a África e o Oriente. Sem possuir grandes mamíferos, a América tropical participaria desse comércio com o que tinha de mais atrativo, essencialmente felinos, primatas e aves - em particular os papagaios, os quais eram embarcados em bom número. Contudo, a julgar pelos documentos do Brasil colônia, esses voláteis podiam inspirar muito pouca simpatia, pois nenhum outro animal - exceto as formigas - foi tantas vezes mencionado como praga para a agricultura. Além disso, alguns psitácidas mostravam-se tão loquazes que inspiravam a séria desconfiança de serem animais demoníacos ou possessos, pois só três classes de entidades - anjos, homens e demônios - possuíam o dom da palavra. Nos dias de hoje, vários representantes dos Psittacidae ainda constituem uma ameaça para a agricultura, enquanto os indivíduos muito faladores continuam despertando a suspeita de estarem possuídos pelo demônio. Transcendendo a mera curiosidade, essa crença exemplifica o quão intrincadas podem ser as relações do homem com o chamado "mundo natural", revelando um universo mais amplo e multifacetado do que se poderia supor a princípio. Nesse sentido, a existência de aves capazes de falar torna essa relação ainda mais complexa e evidencia que as dificuldades de estabelecer o limite entre o animal e o humano se estendem além dos primatas e envolvem as mais inusitadas espécies zoológicas.

PALAVRAS-CHAVE: Papagaio. Psittacidae. Comércio de animais. Agricultura. Pragas. Diabo. Possessão. Bruxaria. Folclore. Novo Mundo. Brasil Colônia.

ABSTRACT: Since ancient times, parrots and their allies (Psittacidae) have fascinated Europeans by their striking colors and notable ability to interact with human beings. The discovery of the New World added new species to the international exotic animal trade, which for many centuries had brought beasts to Europe from Africa and the Orient. Lacking large mammals, tropical

\footnotetext{
1. Professor associado do Departamento de Vertebrados, Museu Nacional UFRJ, Rio de Janeiro (RJ). E-mail: <dante.teixeira@ pq.cnpq.br>.
} 
2. A exata identidade dos periquitos-de-coleira encontrados no mundo greco-romano continua sendo motivo de grande discussão. Embora a maioria dos relatos e imagens não permita uma diagnose precisa, parecem existir elementos suficientes para afirmar que eram conhecidas Psittacula cyanocephala (Linnaeus, 1766), Psittacula eupatria (Linnaeus, 1766) e sobretudo Psittacula krameri (Scopoli, 1769). Como a totalidade das fontes clássicas menciona a "Índia" como a origem dessas aves, boa parte dos autores descarta a presença das subespécies africanas de Psittacula krameri, embora caiba lembrar a observação de Plínio, "o Velho", sobre uma expedição enviada por Nero à Etiópia (ca. 68 A.D.) ter encontrado tais periquitos no atual território do Sudão (Plínio, 1979-1984). Para mais detalhes, vide Amat (2002), Arnott (2007), Boehrer (2004), Jenninson (1937), Pollard (1977) e Toynbee (1973).

3. Ctésias de Cnidos viveu no século $\mathrm{V}$ a.C., tendo passado vários anos na Pérsia como médico do rei Artaxerxes II. Em sua "Indica" - obra conhecida graças à compilação existente na famosa "Bibliotheca" de Photius, Patriarca de Constantinopla - Ctésias é o primeiro europeu a mencionar um

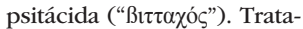
-se provavelmente de Psittacula cyanocephala, malgrado certos autores prefiram atribuir sua descrição à Psittacula roseata Biswas, 1951 (compare Arnott, 2007 e Boehrer, 2004). Essas aves seriam dignas de particular atenção por possuírem a "língua e a voz humanas", falando indiano "como um nativo" ou então grego, caso palavras nesse idioma lhes fossem ensinadas (in Photius, 1920, 1959)

4. Ao tratar do periquito-de-

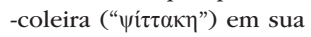

America participated in this trade with its most appealing species, essentially felines, primates and birds - especially parrots - which were shipped in large numbers. It should be noted, however, that at times these birds were not well liked. In fact, according to documents from colonial Brazil, only the ants rank higher than parrots as the animals most often mentioned as agricultural pests. On the other hand, some of these birds were so chatty that people suspected them to be demonic or possessed animals, since only three classes of beings - angels, men and demons - have the ability to speak. Nowadays, several Psittacidae still constitute a threat to agriculture, and the suspicion that extremely talkative birds were demon possessed has also survived. More than a joke or a mere curiosity, this belief exemplifies how intricate man's relationships with the "natural world" may be. In this sense, the existence of birds that are able to speak adds a further twist to these relationships, demonstrating that the problem of establishing a boundary between the animal and the human does not only involve primates, but also includes some unusual zoological species.

KEYWORDS: Parrot. Psittacidae. Animal trade. Agriculture. Pest. Devil. Possession. Witchcraft. Folklore. New World. Colonial Brazil.

Introdução

Desde a Antiguidade, papagaios, periquitos e afins (Psittacidae) despertaram grande interesse na Europa tanto pelo vivo colorido quanto por sua notável capacidade de interação com o ser humano. Se comparados com a maioria das outras aves mantidas em cativeiro, os psitácidas oferecem uma experiência bem mais rica, pois possuem um repertório comportamental muito elaborado e apresentam notória facilidade de reproduzir a nossa fala e os mais diferentes ruídos. Gregos e romanos parecem ter conhecido apenas os periquitosde-coleira do gênero Psittacula² e vários autores - a começar por Ctésias de Cnidos - destacam sua loquacidade. ${ }^{3}$ Segundo Aristóteles, tais periquitos tornarse-iam mais insolentes quando bebiam vinho em demasia, ${ }^{4}$ observação que atravessaria os séculos respaldada pela "Historia Naturalis" de Plínio, "o Velho", 5 e acabaria por granjear para os Psittacidae a fama de consumados apreciadores de bebidas alcoólicas, crença que pode ter inspirado a composição de alguns quadros renascentistas sobre a intemperança (Figura 1). ${ }^{6}$

A expansão portuguesa na costa africana e o posterior estabelecimento de um caminho marítimo para as Índias seriam traduzidos em um fluxo crescente tanto de especiarias e outras cobiçadas riquezas quanto de animais exóticos e seus despojos, realidade que contradiz a propalada visão desse comércio como algo marginal capaz de se articular apenas na ausência de produtos de maior interesse financeiro. Ao lado do marfim, pérolas, carapaças de tartarugas, corais, conchas 
de náutilo e a púrpura do múrex, importavam-se as odoríferas secreções produzidas pelo castor, pelo cervo-almiscareiro e por civetas, grandes quantidades de penas de pavão, peles diversas e chifres de rinoceronte, esses últimos declarados como monopólio real desde 1470. Além dos já mencionados pavões, o comércio de aves vivas compreendia grous, pelicanos e diversos lóris, periquitos e papagaios, enquanto os mamíferos estavam representados por macacos, gazelas e antílopes, guepardos, tigres, leões, leopardos e outros felinos. Tampouco faltavam quadrúpedes de maior porte, sendo conhecida a história do rinoceronte e dos vários elefantes enviados da Índia para Dom Manuel I, "o Venturoso". ' Contudo, vale destacar que esse tráfico não só antecede a expansão europeia dos séculos XV e XVI como podia envolver espécies procedentes de áreas muito distantes, conforme exemplifica o episódio de Frederick II, imperador do Sacro Império Romano Germânico, ter recebido - no ano de 1229 - uma cacatua do "sultão da Babilônia", exemplar retratado em sua famosa "De arte venandi cum avibus" ("Arte da falcoaria"). Séculos mais tarde, uma segunda cacatua apareceria no quadro "Madonna della Vittoria" de Andrea Mantegna, pintura concluída na cidade de Mântua em 1496, portanto três anos antes do retorno de Vasco da Gama ${ }^{8}$ (Figura 2).

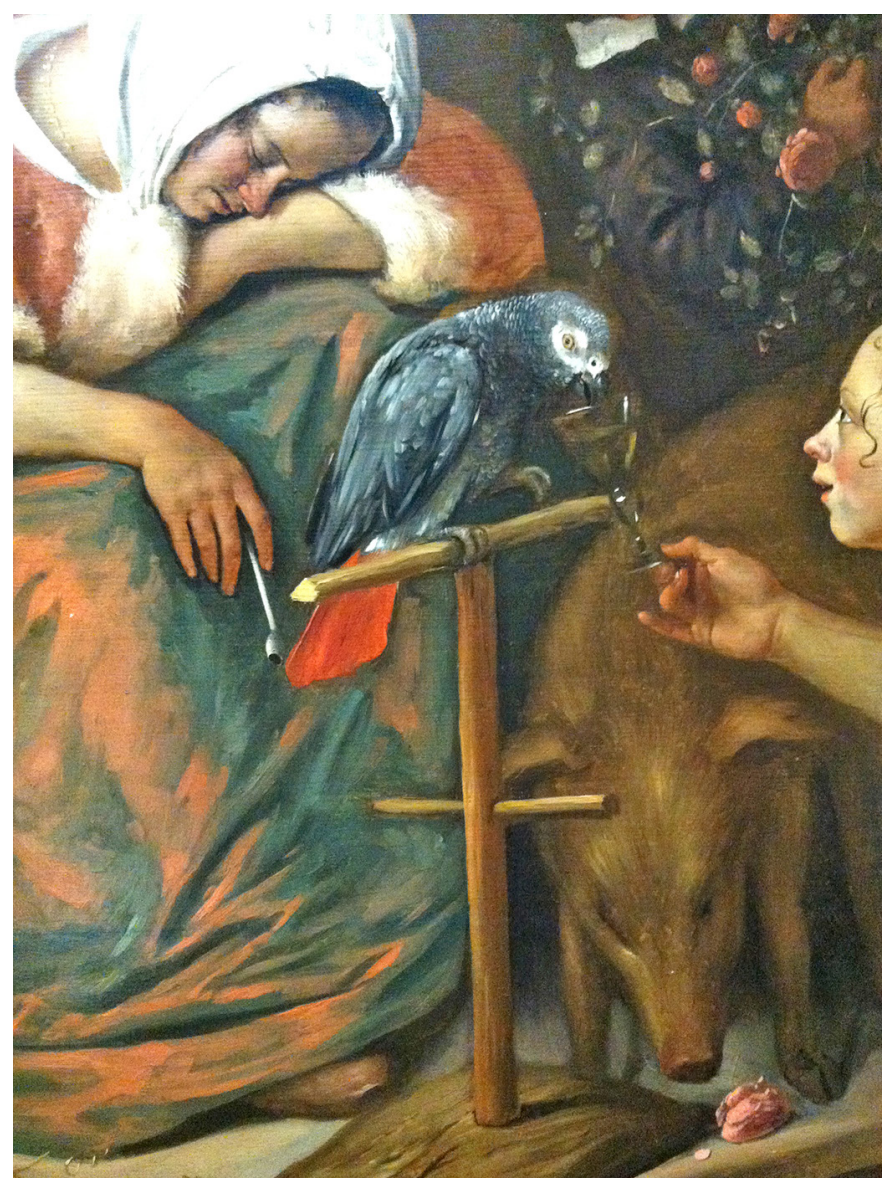

Figura 1 - Detalhe de "Os Efeitos da Intemperança" de Jan Steen (1663-1665), mostrando um papagaio-do-congo, Psittacus erithacus. National Gallery, Londres. Foto Paula de Vries Albertin.
"História dos animais", Aristóteles escreve que "em geral, todas as aves com garras curvas têm o pescoço muito curto, a língua achatada e dotes de imitação [...] o periquito, do qual se diz ter uma língua como a do homem", faria parte desse elenco, tornando-se inclusive "mais insolente quando bebe vinho" (Aristóteles, 1965-1991).

5. De acordo com Plínio, o periquito-de-coleira ("psittacus") "saúda imperadores e pronuncia as palavras que lhe foram ensinadas, sendo particularmente lascivo sob a influência do vinho" ("Imperatores salutat et quae accipit verba pronuntiat, in vino praecipue lasciva" no original; Plínio, 1979-1984).

6. Com efeito, segundo documento datado de 1526, o "parikito" de sir Robert Cecil, secretário de Estado de Elisabeth I, deveria beber apenas "água ou clarete", enquanto Buffon, célebre naturalista francês do século XVIII, menciona explicitamente o grande entusiasmo dos papagaios pelos vinhos espanhol e moscatel (Buffon, 1780, Emerson, 1996 e Grigson, 2016).

7. Bedini (1998), Clarke (1986), Costa (1937) e Lach (1970).

8. Essas imagens já foram atribuídas à Cacatua sulphurea (Gmelin, 1788) de Celebes, Flores, Timor e outras pequenas ilhas do Arquipélago da Sonda, à Cacatua alba (Müller, 1776) das Molucas e à Cacatua galerita Latham, 1790 da Austrália e Nova Guiné. Apesar de conhecida há várias décadas, a cacatua existente no quadro de Andrea Mantegna causou certa comoção nos últimos anos (compare Dalton, 2013 com Dickenson, 2007 e Stresemann, 1951), levando a especulações sobre a Austrália e Nova Guiné terem participado do tráfico comercial com o extremo Oriente em pleno século $\mathrm{XV}$. Não resta dúvida de que 
os Psittacidae eram familiares aos mercadores árabes, além de estarem frequentemente associados ao "sultão da Babilônia" (i.e. ao soberano do Egito, apud Pérez, 2007). Sobre a ave retratada em "De arte venandi cum avibus" (Bibliotheca Vaticana, Pal. lat. 1071), vide Clark (2000) e Yapp (1983), enquanto os animais de estimação na Idade Média foram estudados por Walker -Meikle (2014).

9. Gorgas (1997), Gorgas; Schweinberger (1986), Kellenbenz (1990), Loisel (1912), Meadow (2002), Strehlow (2001) e Teixeira (2011).

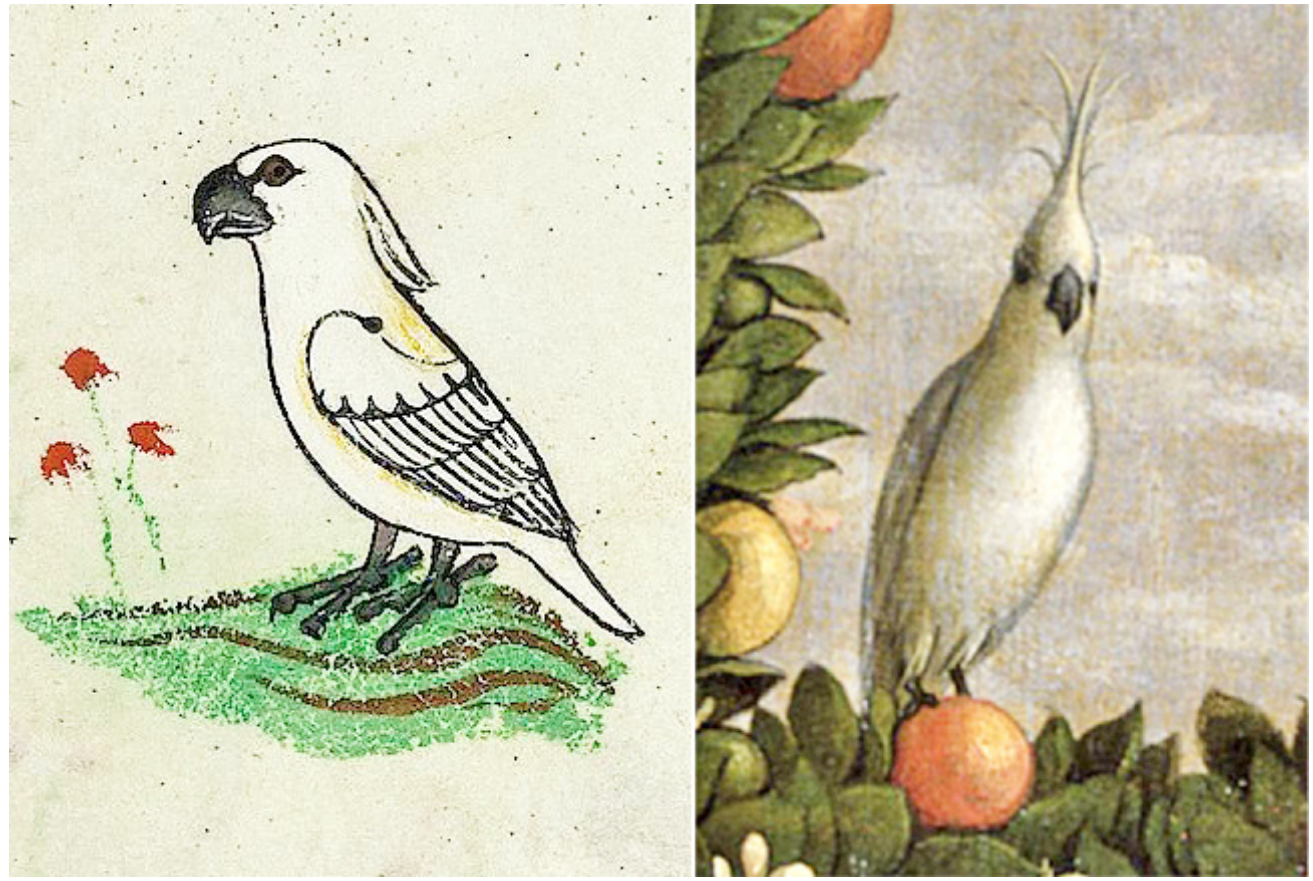

Figura 2 - Da esquerda para direita, detalhes mostrando as cacatuas, Cacatua sp., retratadas na "De arte venandi cum avibus" do imperador Frederick II (ca. 1240) e na "Madonna della Vittoria" de Andrea Mantegna (1496). Bibliotheca Vaticana, Roma e Musée du Louvre, Paris.

crescente fascínio pela fauna do além-mar logo chamaria a atenção dos agentes econômicos envolvidos com os descobrimentos portugueses, entre eles os célebres irmãos Ulrich e Jakob Fugger, os mais abastados mercadores e banqueiros de sua época. Já em 1505, os Fuggers perceberiam o inegável potencial oferecido pelos animais exóticos e seus produtos, no que foram de pronto acompanhados pelos Welsers, outra poderosa família de negociantes alemães. Pelo menos até 1521, os representantes dos Fuggers em Lisboa remeteriam para a sede da empresa em Augsburg macacos, pavões, felinos e diversos psitácidas. Além de exemplares vivos, esse comércio contemplava vultosas partidas de penas de pavão, bem como peles de leopardos, tigres e leões, produtos muito apreciados para a confecção de vestimentas e adornos de luxo. Permanecendo ao alcance apenas dos nobres e dos mais opulentos burgueses, os pavões acabariam sendo criados em larga escala nos arredores de Neusohl, atual Banská Bystrica na Eslováquia, instalação que continuava ativa em 1546. Entre 1520 e 1530, a rota do florescente tráfico promovido pelos Fuggers seria deslocada para Antuérpia, a nova porta de entrada das importações promovidas pela companhia. Sediados em um amplo jardim provido de jaulas e outras facilidades, os funcionários podiam receber um número considerável de animais vindos em navios procedentes de Portugal, Espanha ou Itália e redistribuílos aos ricos compradores de toda a Europa, aproveitando-se do transporte fluvial oferecido pelo Reno. ${ }^{9}$ 
A descoberta da América nada faria além de acrescentar novos elementos ao tráfico de animais exóticos há muito estabelecido pelos europeus com a África e o Oriente. Sem possuir grandes mamíferos, o neotrópico participaria desse comércio com o que havia de mais atrativo, essencialmente felinos, primatas e aves - em particular os papagaios, reunidos em bom número desde a primeira viagem de Colombo. Segundo cronistas como Bartolomeu de las Casas e Francisco López de Gómara, o navegador genovês não só embarcou 40 papagaios nas terras situadas do outro lado do oceano como exibiu os espécimes sobreviventes pelas ruas de Sevilha e na audiência com os reis católicos, evento levado a cabo em Barcelona no dia 3 de abril de 1493. As aves teriam sido muito celebradas por seu belo colorido, pois enquanto algumas eram de um verde brilhante, outras possuíam uma plumagem vermelha ou amarela pintalgada, sendo assaz diferentes daquelas usualmente vistas na corte espanhola. ${ }^{10}$ Passadas pouco mais de três décadas, o número de psitácidas procedentes da América havia crescido tanto que, em 1526, o cronista Gonzalo Fernández de Oviedo y Valdés se recusaria a incluí-los em sua "Natural Historia de las Indias" por serem demasiado comuns, não valendo a pena perder tempo falando neles. " A julgar pelos comentários do médico Nicolás Monardes, nos idos de 1565 chegariam anualmente mais de cem naus carregadas de papagaios, macacos, felinos, aves de rapina e outros produtos do Novo Mundo. ${ }^{12}$

Entre as novidades do além-mar trazidas por Pedro Álvares Cabral no retorno de sua aziaga viagem à Índia (1500-1501), nenhuma atrairia tanto a atenção dos europeus quanto duas araras-vermelhas obtidas em terras brasileiras. Descritas entusiasticamente pelo cronista Pero Vaz de Caminha como "papagaios vermelhos muito grandes e formosos", essas aves seriam consideradas dignas de particular admiração por todos os observadores da época, inclusive os diferentes missivistas italianos prontos a dar notícia sobre as navegações ibéricas aos seus conterrâneos. Esse seria o caso de Giovanni Matteo Camerini, chamado "Il Cretico", o erudito secretário de Domenico Pisani di Giovanni, embaixador de Veneza na Espanha e Portugal. Em carta datada de 27 de junho de 1501, "II Cretico" prestaria informações ao doge Agostino Barbarigo e empregaria pela primeira vez a expressão "Terra dos Papagaios" ("Terra de li Papaga") para referirse ao Brasil, termo que seria consagrado após ganhar as páginas do "Paesi Novamente Retrovati" de Fracanzano da Montalboddo (1507), um dos mais prestigiosos "livros de viagens" do século XVI. ${ }^{13}$ Em 1504, a enigmática expedição de Gonçalo Coelho teria voltado à Lisboa com uma carga de pau-brasil, macacos e papagaios, enquanto a famosa "nau Bretoa" transportaria 72 animais - inclusive 15 papagaios e 22 periquitos - em 151 1. ${ }^{14}$ Nesse sentido, também vale lembrar o episódio da "Pélerine", talvez o caso de contrabando mais famoso do Brasil colônia. Capturada por um navio português em setembro de 1531, essa embarcação francesa estava levando para a Europa nada menos de 3000 peles de "leopardos" e de outros animais, 300 macacos e 600 papagaios falantes do francês, cada qual estimado em seis ducados, quantia nada desprezível na
10. Segundo Francisco López de Gómara (1552), Colombo "tomo diez Indios, quarẽta papagayos, muchos gallipavos, conejos (que llamã hutias), batatas, axies, maiz, de que hazẽ pan, y otras cosas estrañas, y diferentes de las nuestras, para testimonio delo que auia descubierto [...] Presento a los reyes el oro, y cosas que traya del otro mundo. Y ellos, y quantos estauan delante, se marauillaron mucho en ver que todo aquello, excepto el oro, era nueuo, como la tierra dõde nascia. Loaron los papagayos por ser de muy hermosas colores. Unos muy verdes, otros muy colorados, otros amarillos con treynta pintas de diuersa color. Y pocos dellos parecian a los que de otras partes se trac̃". Bartolomeu de las Casas, porém, limita-se a comentar que o Almirante "llevó papagayos verdes muy hermosos y colorados, y guayças, que eram unas carátulas hechas de pedrería de huessos de pescado" (Las Casas, 1875).

11. "Papagayos ay muchos $y$ de tantas maneras $y$ diuersidades que seria muy larga cosa dezirlo: y cosa mas apropriada al pinzel para darlo a entender, que no a la lengua. Pero porque de todas las maneras que los ay, los traen a España, no ay para ̃̃ se pierda tiempo hablando en ellos" no original (Oviedo y Valdés, 1526).

12. "Traen de aquellas partes, ansi mismo Papagayos, Monos, Griphos, Leones, Gerifaltes, Açores, Tigres, Algodon, Grana para teñir, Cueros, Açucares, Cobre, Brasil, Ebano, Azul: y de todo esto es tanta cantidad, que vienen cada año casi cien Naos cargadas dello, que es cosa grande, y riqueza increyble" no original (Monardes, 1565). Um século mais tarde, o frei Andrés Ferrer de Valdecebro acrescentaria que a Espanha estava povoada de papagaios, os quais tinham passado a 
não valer tanto ("Està poblada oy España destos paxaros, por los muchos que traen Galeones y Flotas. No tiene la estimacion oy que tuuieron vn tiempo en Roma, porque en tiempo de Mario Carón valia vn Papagayo tanto como el mejor esclauo" no original (Valdecebro, 1670).

13. Montalboddo (1507), vide também Teixeira; Papavero (2006)

14. Segundo Góis (1566), esta carga abarcaria um "páo vermelho, a que chamão brasil, bogios e papagaios". Sobre os animais da "nau Bretoa", vide Teixeira; Papavero (2010).

15. Com a discreta anuência do rei de França e tendo como armador Bertrand d'Ornessan - Barão de Saint-Blancard e comandante da esquadra gaulesa no Mediterrâneo - a "Pélerine" deixaria Marselha em dezembro de 1530 com a missão de estabelecer uma praça-forte no Brasil. Após arrasar a feitoria existente na foz do rio Igaraçu, Pernambuco, em março de 1531 , os invasores ergueriam uma nova fortaleza na ilha de Itamaracá, zarpando de volta à França em julho desse mesmo ano. Em setembro de 1531 , porém, a "Pélerine" seria capturada por um navio português ao largo de Málaga, Espanha, ação contestada em juízo pelo Barão de Saint-Blancard, disputa que explicitaria a natureza da carga apreendida. Vide Manuel Emílio Gomes de Carvalho (1909), Sanceau (1956), Simonsen (1937) e Pero Lopes de Sousa (1927).

16. Teixeira; Papavero (2010).

17. Tal como os antigos cronistas, muitas vezes utilizaremos esse termo em seu sentido mais abrangente, englobando os Psittacidae em geral. época. ${ }^{15}$ De fato, os animais exóticos eram um produto de luxo, já que um único periquito ou papagaio chegava a valer 226 reais na Lisboa manuelina, total equivalente a cerca de $28 \%$ do soldo de um soldado raso, $37 \%$ do soldo médio de um pedreiro e mais de $80 \%$ do soldo de um trabalhador não qualificado. ${ }^{16}$

\section{Os papagaios como pragas}

Analisado por diversos autores, o inegável encanto despertado pelos papagaios ${ }^{17}$ constitui um fato bem conhecido que dispensa maiores comentários. ${ }^{18}$ No entanto, essas aves por vezes inspirariam muito pouca simpatia, um aspecto amiúde esquecido da contraditória relação mantida entre os colonizadores e a fauna do Novo Mundo. Com efeito, desde o período pré-colombiano os psitácidas eram capazes de produzir autênticas razias em plantações, as quais se viam atacadas por contingentes maciços de aves famintas. A julgar pelas cenas retratadas na cerâmica, ourivesaria e outros objetos do cotidiano (Figuras 3 e 4), os milharais eram particularmente visados e necessitavam ser protegidos, fato registrado já em 1558 por Gerónimo de Bibar, um dos companheiros de Pedro de Valdivia na conquista do Chile. ${ }^{19} \mathrm{Cem}$ anos mais tarde, a "Historia general de el Reyno do Chile" do jesuíta Diego de Rosales forneceria maiores detalhes ao destacar que os papagaios - provavelmente Cyanoliseus patagonus (Vieillot, 18 18 ) - em pouco tempo arrasavam as plantações de trigo, milho, cevada e outros cereais, chegando mesmo a desenterrar as sementes recém-plantadas, conseguindo escapar às pedradas dos rapazes postos a combatê-los pelo aviso de sentinelas pousadas em árvores próximas (Figura 5). ${ }^{20}$

Vários outros cronistas da América Espanhola fariam observações detalhadas sobre esse tema, caso dos jesuítas oitocentistas envolvidos com as reduções da Bacia do Rio da Prata. Nesse sentido, Sanchez Labrador afirma serem os papagaios do Paraguai numerosos o suficiente para causarem muitas fadigas e problemas, pois seu "olfato agudíssimo e visão muito perspicaz" logo faziam-nos perceber os milharais, que eram prontamente assaltados e destruídos caso falhasse a vigilância dos responsáveis. De manhã cedo ou ao final da tarde, os psitácidas chegavam em bandos muito grandes e pousavam às centenas nos pés de milho, pouco importando os gritos, pedradas e mesmo tiros disparados pelos lavradores. Também atacavam os pomares, sendo apreciadores de laranjas e limões. ${ }^{21}$

$\mathrm{Na}$ "Historia de la conquista de las provincias del Paraguay, Río de la Plata y Tucumán", o padre Pedro Lozano faria um relato semelhante ao destacar os enormes esquadrões de voracíssimos papagaios capazes de aniquilar os campos de cultivo com notável rapidez, ${ }^{22}$ enquanto seu confrade Florián Paucke acrescenta serem as plantações de milho atacadas todos os anos por uma "peste de papagaios" que não respeitava sequer uma única espiga e tornava-se demasiado prejudicial pelo fato de os invasores danificarem mais do que podiam comer, deixando o solo coberto de grãos mordidos e roídos. Além de dar tiros de 
fuzil e empregar muitos vigias armados com arcos para espantá-las, Paucke promovia incursões em bosques vizinhos para queimar os ninhos que essas pragas construíam nos ramos das árvores, descrição indicativa da caturrita, Myiopsitta monachus (Boddaert, 1783), como uma das espécies responsáveis por esses saques periódicos (Figura 6). ${ }^{23}$

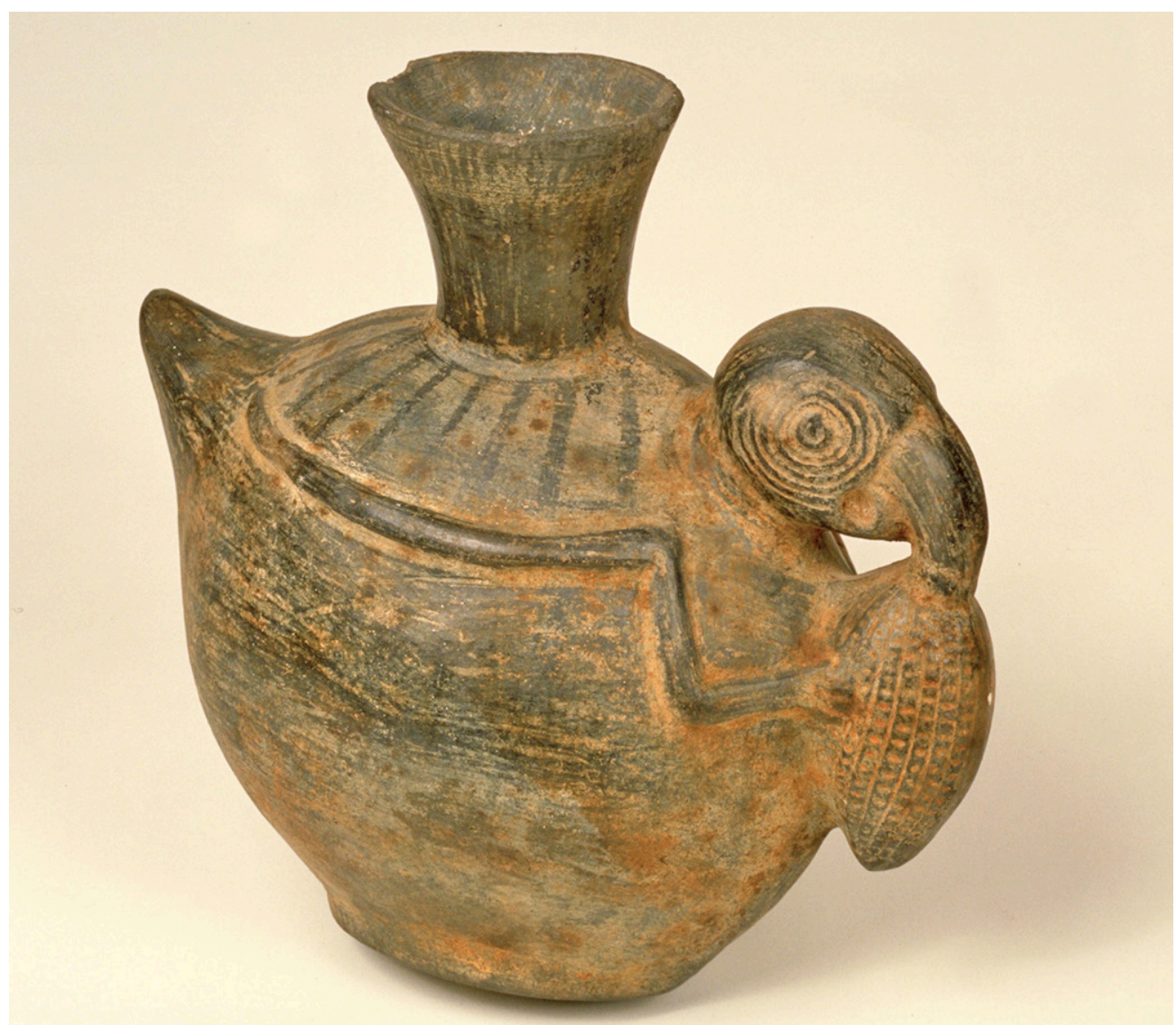

Figura 3 - Vaso de cerâmica mostrando um psitácida comendo uma espiga de milho. Cultura Chimú, norte do Perú, ca. 800-1300 A.D. Yale Peabody Museum of Natural History, New Haven.

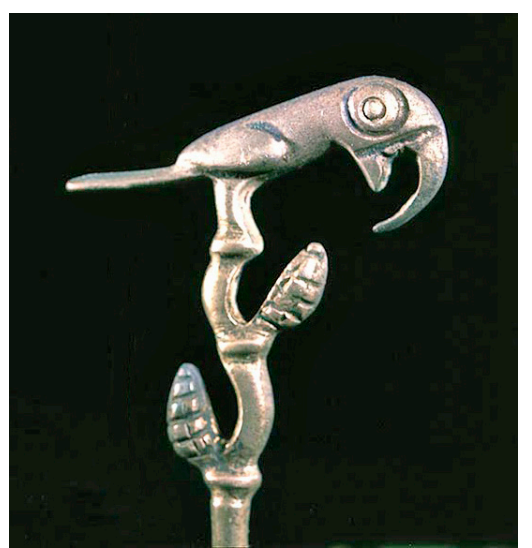

Figura 4 - Alfinete de prata mostrando um psitácida e espigas de milho. Cultura Chimú, norte do Perú, ca. 900-1470 A.D. Dumbarton Oaks Research Library and Collection, Georgetown.
18. Vide, por exemplo, Boherer (2004), Robbins (2002) e Verdi (2007).

19. "El maíz, cuando lo siembran en octubre, que es como abril en España, siémbrase en tierra enjuta algunos y otro[s] en regada de cinco o seis dias cavando la tierra con aquellas estacas, y otros echando el maíz en los hoyos que serán tres o cuatro granos. Cuando nacen guárdanlo, que las aves no lo coman, y después que está nacido de dos o tres hojas está el campo y hierba seca, que hay mucha y muy alta" no original (Bibar, 1996).

20. "Vuelan en tropas y en poco tiempo talan una sementera de trigo, maiz, cebada y otros granos, y aun quando acaban de arrojar la semilla, la desenvuelven y desentierran, dejando drefraudadas las esperanzas de los labradores, y assi suelen armar contra ellos a los muchachos, que a vozes y pedradas los hazen huir. Pero siempre viven con tanta cautela y vigilancia en estos robos, que ponen en un arbol o parte superior un papagayo de centinela, el qual en viendo gente les avisa de la venida de sus enemigos con gritos importunos, y porque no cargue sobre solo uno el trabajo, mudan y suceden los unos a los otros en la centinela" no original (Rosales, 1877).

21. "Se multiplican tanto los paracaus de todas as especies en el Paraguay que en lugar de diversión sirven de fatiga y molestia. Tienen un olfato agudísimo y una vista muy perspicaz. Con estas dos prendas, perciben las sementeras de maíz, las asaltan, y si falta vigilancia en los labradores, las destrozan y talan. Pasan de algunos centenares a veces los que se sientan en las cañas de una sementera de dicho grano, o como por acá se explican en una chacra. Sus principales horas 
son por la madrugada, al rayar del dia, hasta las siete u ocho de la mañana, y por la tarde, unas dos horas o tres antes de ponerse el sol, hasta que este astro quiere ocultar-se. En estos tiempos acuden tan grandes bandadas que causan admiración. Ojeados de los guardianes con gritos y pedradas, y tal vez con escopeta, revolotean un poco y porfian en sentarse y destrozar [...] Meten una vocinglería intorelable [...] pero están muy silenciosos cuando logran asaltar una chacra de maíz [...] Gustan también mucho de las pepitas de las naranjas y limones, sean dulces o agrios" no original (Sanchez Labrador, 1968).

22. "Los papagayos son tantos en todas estas provincias, pero con especialidad en la del Paraguay, que con dificuldad se hallarán más en otras regiones [...] tan numerosas que cubren en nubes los aires y volando de las arboledas a los campos sembrados los talan y destruyen en breve espacio, siendo preciso usar de suma diligencia y vigilancia para librar los labradores su trabajo de las invasiones de estos importuníssimos enemigos, que formados en escuadrones, acometen por todas partes, con igual daño al que pudieran hacer el ejército numeroso. Son voracíssimos y todos armados de pico curvo, que corta como si fuera de acero; es cosa prodigiosa ver la puntualidad con que acuden a sus tiempos, como si los convocaran de propósito, o tuviesen prevenidas espias que les avisasen cuando están maduros los frutos y sazonadas las mieses. Pasan la noche en arboledas cercanas y al salir del dia vienen en bandadas numerosas con tan grande vocería que, con volar muy altos, se sienten en la tierra como si estuvieran muy cerca" no original (Lozano, 2010).

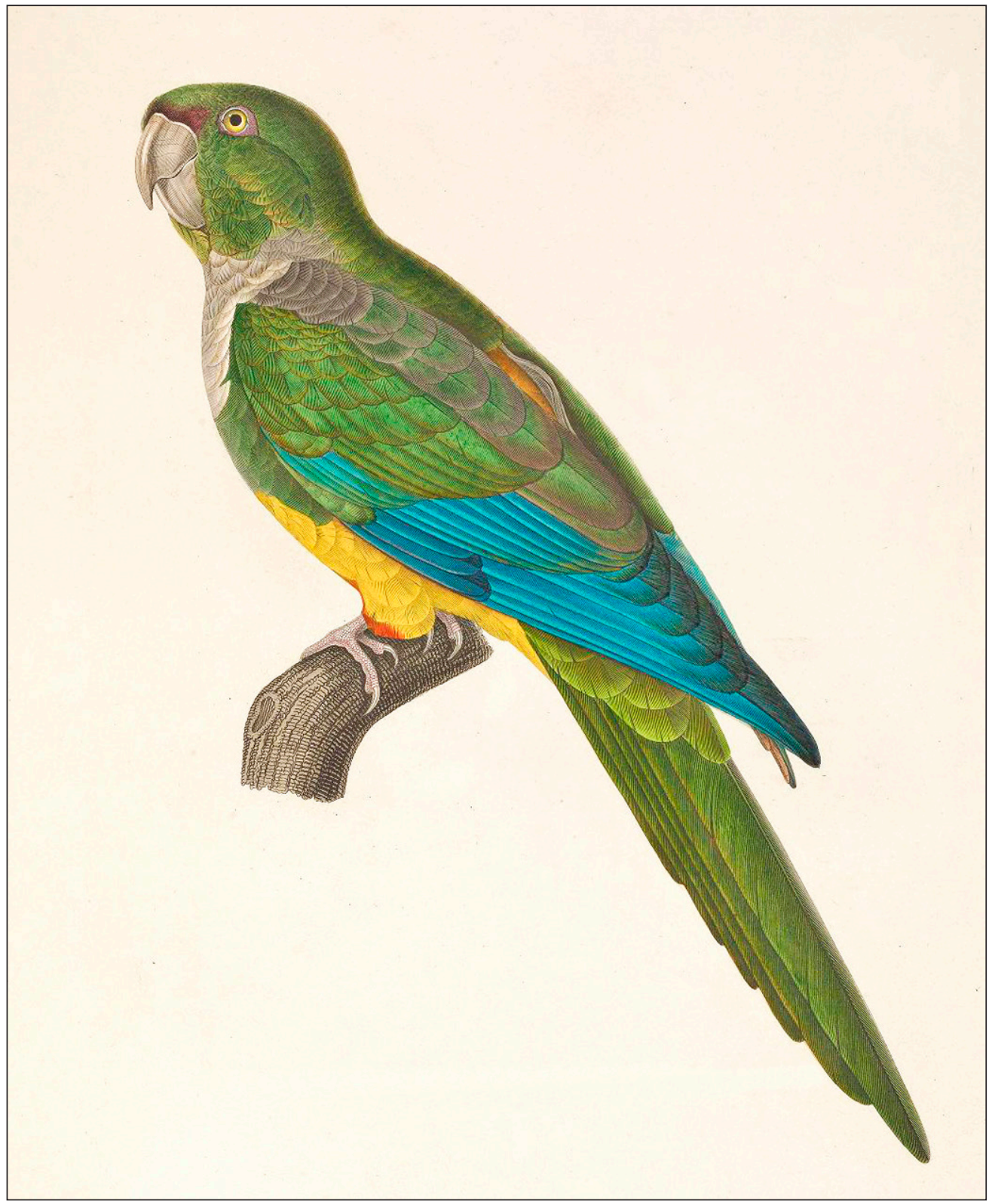

Figura 5 - Papagaio-barranqueiro, Cyanoliseus patagonus, segundo ilustração da "Voyage autour du monde" de Renè Primevère Lesson e Prosper Garnot (1 826).

Exceto pelas formigas, ${ }^{24}$ nenhum outro animal foi tantas vezes mencionado como praga pelos documentos do Brasil colônia quanto os Psittacidae. Formando bandos impressionantes capazes de escurecer os céus, essas aves eram - nas palavras do jesuíta quinhentista Fernão Cardim - "infinitas, mais que gralhas, zorzais, estorninhos, nem pardais da Espanha e [...] destroem as milharadas; sempre andam em bandos e são tantos que há ilhas onde não existem mais que 
papagaios". ${ }^{25}$ Mesmo que facilitasse o crescente tráfico de espécies exóticas, semelhante abundância constituía séria ameaça para a agricultura, havendo referências particularmente constantes a prejuízos em plantações de milho. Em sua famosa "Epistola quam plurimarum rerum naturalium quae S. Vicenti (nunc St. Pauli) provinciam incolunt", datada de 31 de maio de 1560, o padre Joseph de Anchieta

\section{mencionaria serem}

os papagaios mais comuns aqui do que os corvos e de diferentes espécies, todos bons para se comer; alguns deles produzem prisão de ventre; outros imitam a voz humana; outros há que, comendo o milho quando está granado, fazem de maneira que, quando descem para comer, fique sempre um ou dois no alto de uma árvore como vigia, espiando o lugar por todos os lados; em vendo alguém aproximar-se, tocam rebate e fogem todos; mas se não houver perigo algum, quando os outros fartos sobem, descem os vigias por sua vez para comer. ${ }^{26}$

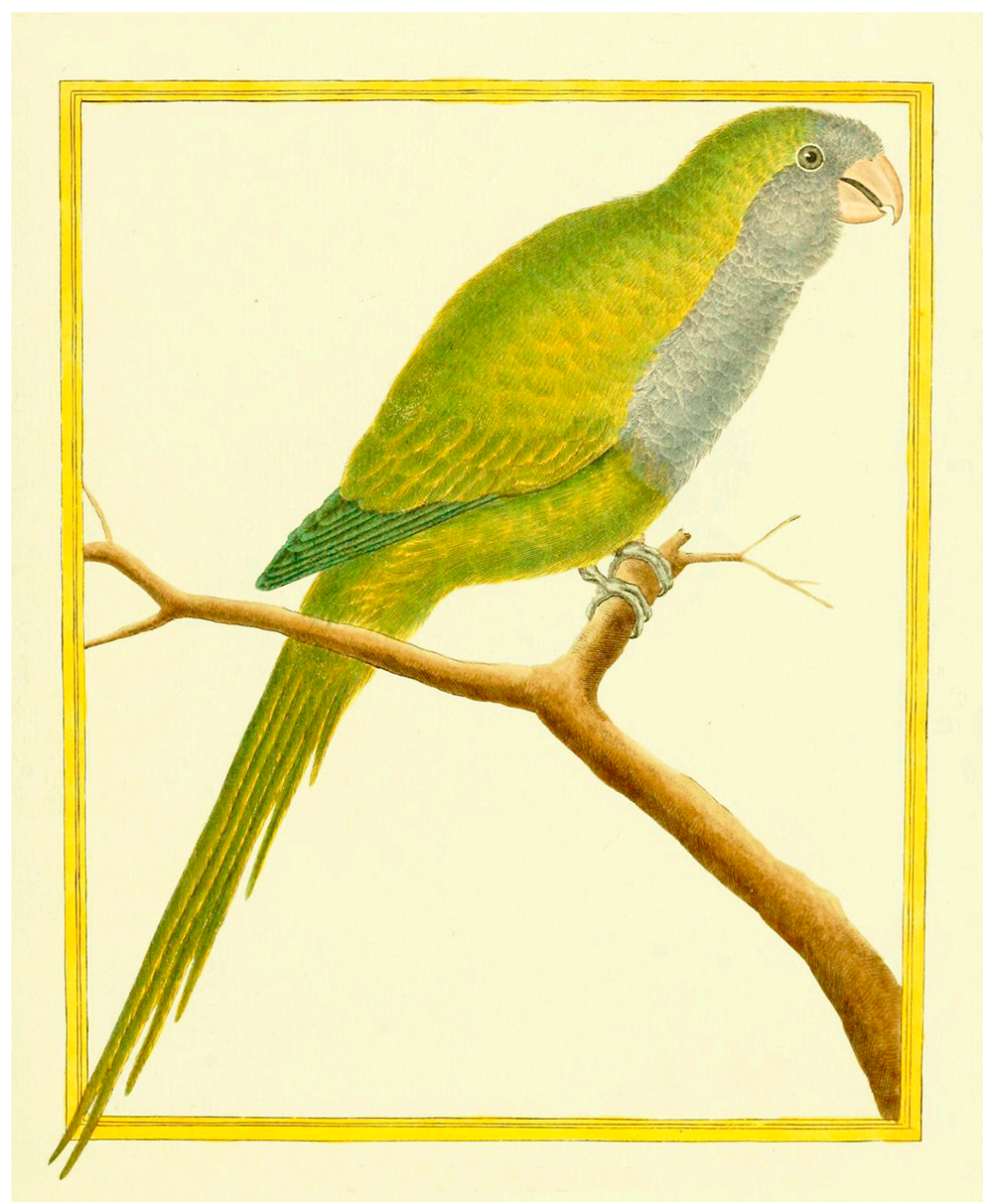

Figura 6 - Caturrita, Myiopsitta monachus, segundo ilustração das "Planches enluminées d'Histoire Naturelle" (ca. 1765-1783).
23. "Hay allá una gran abundancia de loros de diversas clases y tamaños [...] Son muy dañinos en los campos de maíz o cucurus. En mi reducción yo tenia todos los años la peste de loros en el maíz. Ellos no dejaban indemne a ninguna espiga. Sucedia que muchas varas de maíz estaban tan deshojadas que los marlos de las espigas se hallaban sin granos algunos. Por eso yo debía hacer vigilar los campos y debía emplear no sólo un guardián sino muchos muchachos con flechas que los ahuyentaban. Yo mismo estube obligado a matarlos o a ahuyentarlos mediante el fusil. Lo más perjudicial en estas aves es la costumbre de dañar más de lo que comen, pues debajo de las cañas de maíz todo está lleno de granos mordidos y roídos. Ellos no vuelan en parejas sino que se reúnen en cantidad tan grande como los estorninos $\mathrm{y}$ en diversas bandadas invaden por cientos en los campos y como yo habia dividido los campos en grandes secciones para la rotación, cuando eran perseguidos en un lado volaban al otro y devastaban el maíz por todas partes. Para alejar o a lo menos disminuir el mal, cabalgaba yo todos los años con cinquenta o más muchachos a los bosques de algarobo sitos en derredor donde ellos tejen sus nidos sobre los mencionados árboles en el mes de Februario donde ellos ya habían empollado sus críos y los tenían ya en mayor parte emplumados. Cada muchacho tenía una vara larga en cuya punta se había atado un manojo de paja [...] Se ponía fuego a este manojo, se mantenía debajo del nido con lo que éste se incendiaba y se escapaban cuantos podían de todos los críos existentes adentro, otros caían semi asados hacia abajo junto con el nido en llamas. Yo hacía juntar todos los críos vivos y asados a 
medias y meterlos en dos canastos preparados al efecto. En casa yo y también mis muchachos teníamos bastante de éstos para comer" no original (Paucke, 1942-1944).

24. Tais referências dizem respeito sobretudo às saúvas, Atta spp. (Hymenoptera, Formicidae). Existe uma ampla documentação disponível sobre esses insetos que ainda não foi devidamente trabalhada, embora autores como Jacoby (1946), Lenko; Papavero (1979) e Santos (1957) tenham publicado interessantes observações sobre o assunto.

\section{Cardim (1939).}

26. "Psittaci frequentiores, quam istic corvi, et bi quidem diversorum generum, omnis esui apti, quorum alii sistendae conductur alvo; alii humanas voces imitantur; alli, qui comedendo millio, cum iam granatum est, operam impendentes catervatim volitant, ita se gerunt, cum ad pastum descendunt, ut semper unus aut duo in summo arboris cacumine, velut in specula, remaneant; Qui omnen speculantes quoquo versus locum, si quem appropinquare cernut, receptui canunt, et aufigiunt omnes; si vero nibil imminet periculi, cum illi saturati fuerint, et descendunt ad pastum speculatores" no original (Anchieta, 1812).

27. "Há outros papagaios, a que chamam curicas, que são todos verdes e não têm mais que só o queixo amarelo e algumas penas nas asas encarnadas [...] criam em ninhos nas árvores, de onde fazem grande dano nas searas de milho [...] Há outros pássaros todos verdes, maiores que os tuins, que têm o bico branco voltado, toucado de amarelo e azul [...] andam em bandos destruindo as milharadas" no original (Gabriel Soares de Sousa, 1938).
Malgrado não dedique maior atenção ao tema, Gabriel Soares de Sousa faria comentários semelhantes envolvendo tanto papagaios quanto periquitos por volta de 1587.27

mesmo pode ser observado em relatos da primeira metade do século XVII, pois a "História dos animais e árvores do Maranhão" faz clara alusão aos estragos promovidos pelos maracanãs - Primolius maracana (Vieillot, 1816 ) - nas searas de milho (Figura 7). ${ }^{28}$ Mais significativos, todavia, são os trechos do "Diálogo das grandezas do Brasil" dedicados às "jandaias" - quiçá Aratinga aurea (Gmelin, 1788) -, ali descritas como "pássaros do sertão" que vinham para o litoral a fim de se aproveitarem da safra do milho, pois eram pertinazes ao ponto de não serem afugentadas por gritos ou pelo estrondo do bater de bacias, resistindo aos lavradores até mesmo quando algumas eram mortas a pancadas. ${ }^{29}$

Denúncias a esse respeito prosseguiriam com poucas variações ao longo do século XVIII, tendo atraído a atenção de personagens importantes da administração colonial. Com efeito, no segundo semestre de 1788, o tenentegeneral José Arouche de Toledo Rendon ressaltava os problemas criados pelos papagaios na Capitania de São Paulo:

Os passaros de bico redondo que são as araras, papagaios, maitacas, maracanans, araguarys, tiribas e periquitos ${ }^{30}$ etc. ao mesmo tempo em que o milho está maduro não se sustentam de outra coisa. Todos vêem com os seus olhos o estrago que o público padece por causa dessas aves. Sucede, às vezes, que se o lavrador não é diligente, não chega a colher a roça, porque eles a comem toda, o que sucede ordinariamente aos que plantam tarde porque então toda a multidão concorre para essas roças; mas pode-se dizer que, em regra, estas aves comem a quarta parte das roças e isto faz um prejuizo de muitos mil alqueires. Deve-se por todo o cuidado em extinguir uns passaros que comem a quarta parte do pão de uma capitania inteira. Em muitos lugares de Portugal consta que os lavradores são obrigados a trazer anualmente certo número de cabeças de pardais ao Conselho debaixo de certas penas: entretanto, aquelas avezinhas não fazem a decima parte do dano que faz um papagaio ou uma maitáca. Por isso, será de grande utilidade que os corregedores deixem provimentos em cada uma das camaras para que os lavradores dêm certo número de bicos. Isto já lembrou louvadamente a Camara de Parnaíba, mas esta só nada pode fazer e é preciso que a perseguição seja em toda a parte [...] As colheitas duram noventa dias; uma ave desta come diariamente uma espiga e $500[\ldots]$ comeriam 45000 espigas, que são 180 alqueires. ${ }^{31}$

Na tentativa de evitar perdas capazes de comprometer a sobrevivência de todo um núcleo urbano, as autoridades do Brasil colônia terminariam por instituir medidas arbitrárias e impopulares voltadas para o controle das pragas da agricultura. Em torno de 1798, um decreto da Câmara da cidade de Fortaleza, na época com cerca de 10.000 habitantes, obrigava os lavradores, sob severa pena de prisão, a "fazerem o plantio de cereaes" e apresentarem, todos os anos, "trinta cabeças de papagaios, maracanãs e periquitos". ${ }^{32}$ Tais providências, entretanto, não estavam restritas aos psitácidas, pois 4.000 réis de multa teriam sido cobrados, nos idos de 181 1, a pessoas que - contrariando as determinações da Câmara de São Paulo - não haviam apresentado as cabeças de "viras e ticos" 
como exigido por lei. A 4 de novembro de 1820, um novo edital referente às freguesias da cidade de São Paulo determinava a cada lavrador chefe de família apresentar, em todo o corrente mês de dezembro, 24 cabeças de "viras" sob pena de ter de pagar uma multa de 1.200 réis pela contravenção. ${ }^{33}$ Instrumentos desse tipo parecem ter sido bastante comuns em boa parte do Novo Mundo desde o século XVII, conforme atesta o "Act for the incouragement of Killing and Destroying Beasts of Prey and Birds" implantado na Carolina do Sul, Estados Unidos, em 10 de março de 1790. ${ }^{34}$

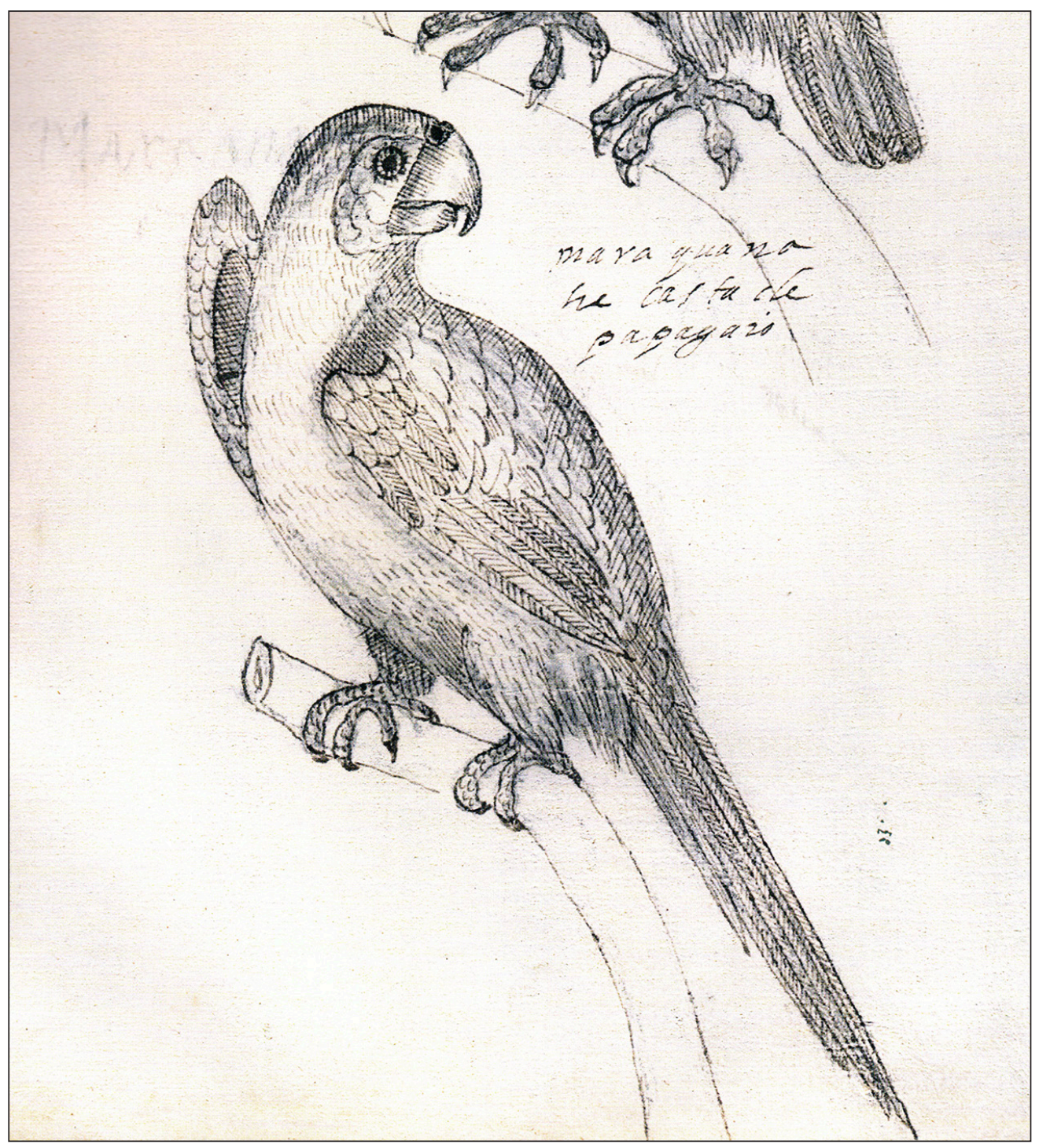

Figura 7 - $\bigcirc$ "maraquana", Primolius maracana, retratado na "História dos Animais e Árvores do Maranhão" (1624-1626). Arquivo Histórico Ultramarino, Lisboa.
28. "Maraquana he pasoro tamanho como papaguio tem o rabo dum palmo de comprido tem o biquo e os peis como papaguaio e he uerde tiramdo damarelo e pardo e uerde mar e he hũ pacoro que faz muita perda aos lauradores pera apor o milho que o quome todo que sempre o amdam estar a olhar" no original (Cristóvão de Lisboa, 1967, 2000). Embora seja geralmente atribuído ao frei Cristóvão de Lisboa, esse manuscrito na realidade parece ter sido elaborado por um francês ou por alguém que tivesse bastante familiaridade com a língua francesa (compare Cristóvão de Lisboa, 1967, 2000, com Papavero; Teixeira, 1999, 2000). Para a identificação desse maracanã, vide Frade (1984) e Oren (1990).

29. "Hyendaias são outros passaros que se criam no sertão; e, ao tempo da colheita das novidades, principalmente dos milhos, descem ás fraldas do mar pera se aproveitarem do cevo delles, e nisto são tão importunas que custa muito trabalho o defende-las delles; porque não basta grandes gritos nem estrondos de bacias, nem o matarem-nas ás pancadas, pera se desviarem das milharadas; em tanto que já vi alguns homens postos em affronta com ellas" no original (Brandão, 1930).

30. Provável referência, respectivamente, a espécies dos gêneros Ara, Amazona, Pionus, Primolius, Diopsittaca, Aratinga, Pyrrhura e Brotogeris (Teixeira, 1998).

31. Rendon (1915).

32. Cruz Filho (1931).

33. Nuto Sant'Ana (in João de Paiva Carvalho, 1942). Além do proverbial tico-tico, Zonotrichia capensis (Statius Muller, 1776), es- 
se documento também parece se referir ao "vira-bosta", nome geralmente atribuído a diferentes ictéridas pertencentes ao gênero Molothrus.

34. "An Act for the incouragement of Killing and Destroying Beasts of Prey and Birds: Whereas the Planters of this Province do yearly suffer considerably damage by birds and beasts of prey in their stock and crops, whereby notwithstanding their continuall care, they are impoverished and discouraged; For prevention whereof, I. Be it enacted by his Excellency John Earl of Bath, Palatine, and the rest of the true and absolute Lords and Proprietors of this Province, by and with the advice and consent of the members of the General Assembly, now met at Charlestown for the south west part of this Province, And it is enacted by the authority of the same, That every person or persons that shall kill or destroy the small Black Birds and Rice Birds shall receive half a royall per dozen, and for Crows, Jack Daws and Larks shall receive one royall and a half per dozen, the birds or heads thereof being brought to the next Justice of the Peace and by them being burnt, to be payed out of the public treasury by a note under the hand of the said Justice of the Peace for the time being, which said note shall be a sufficient discharge for the same. II. And be it further enacted, That whatsoever white man shall destroy and kill Wolf, Tyger, Wildcat or Bear, shall have ten shillings for each, bringing the head thereof to the next Justice as above expressed; and every Indian for killing every Wolf, Tyger or Wildcatt, shall have for each five shillings, to be paid by the Justice and be reimbursed by the Receiver; and the heads of the said beasts are presently to be burnt or

\section{Os papagaios demoníacos}

Embora tenha sido registrada em outras aves como os mainás (Sturnidae) e os corvos, pegas e gaios (Corvidae), a capacidade de imitar a nossa fala acabaria por constituir um elemento determinante no fascínio exercido pelos papagaios, muitas vezes assumindo contornos dos mais surpreendentes. Em certo sentido, os autores clássicos não estavam de todo equivocados ao associar semelhante habilidade ao fato de os Psittacidae possuírem uma língua carnosa amiúde descrita como "humana", 35 pois uma pesquisa recente ressalta o papel central desempenhado por esse órgão em todo o processo, 36 levando a imitações acuradas o suficiente para replicar a exata entonação de uma dada pessoa algo digno de nota se considerarmos que esta era a maneira mais usual de alguém ouvir a reprodução de sua própria voz antes da invenção dos primeiros fonógrafos no final do século XIX. ${ }^{37}$ A faculdade de emular a linguagem propriamente dita e outros sons - gargalhadas, soluços, gritos, vozes de animais e numerosos ruídos mecânicos - varia sobremaneira tanto de espécie para espécie quanto entre indivíduos da mesma espécie. Apesar de diferentes psitácidas mostrarem-se aptos a realizar proezas dignas de nota, o papagaiodo-congo, Psittacus erithacus Linnaeus, 1758, e certos papagaios do Novo Mundo pertencentes ao gênero Amazona parecem ser os representantes mais loquazes, seguidos pelo periquito-australiano, Melopsittacus undulatus (Shaw, 1805), e os já mencionados periquitos-de-coleira, Psittacula sp. ${ }^{38}$

desempenho de alguns exemplares desperta a atenção tanto pelo extenso vocabulário como pela aparente coerência da fala, a qual pode se mostrar bastante articulada, conferindo a impressão de uma sagacidade e eloquência inacreditáveis em termos de um simples bípede emplumado. Com efeito, na década de 1980, a dupla campeã de diversas competições internacionais de aves faladoras - um papagaio-do-congo chamado "Jeacot" e um papagaio-verdadeiro, Amazona aestiva (Linnaeus, 1758), batizado de "Iteau" - possuía um léxico composto por mais de 500 palavras - portanto equivalente ao de uma criança de 2 anos - e atendia a comandos do tipo: "Jeacot, mande lteau imitar um gato", ao que Jeacot ordenava "imite um gato" e Iteau respondia "miau, miau, miau". 39 Há poucas décadas, os experimentos levados a cabo com Alex - outro papagaio-docongo - terminariam por alcançar grande notoriedade, pois ele tanto dominava um vocabulário de 100 palavras como era capaz de distinguir mais de 100 objetos pelo formato, colorido e material, algo não igualado por nenhuma outra espécie viva de ave ou mamífero, tendo uma capacidade intelectual comparável à de uma criança de 4 a 5 anos. Apesar de críticas posteriores sugerirem tratar-se de um sofisticado caso de condicionamento, sem dúvida alguma as atuações de Alex eram marcantes o suficiente para convencer qualquer leigo de estar diante de um organismo inteligente provido de algum tipo de consciência. ${ }^{40}$

No medievo, pensava-se que os papagaios tinham nascido no paraíso terrestre e habitavam o monte Gilboa das escrituras, portanto vivendo nas regiões 
secas do Oriente por temerem que a chuva arruinasse sua colorida plumagem. Esse conceito de uma ave extremamente "pura" e "limpa" seria logo associado à imagem de Cristo e Nossa Senhora, ambos não maculados pelo pecado original (Figura 8). Por sua capacidade de reproduzir a voz humana, os psitácidas também acabariam simbolizando a Anunciação, pois havia a crença de sua fala mais típica ser "ave" ("salve" em latim) - a mesma palavra usada pelo Arcanjo Gabriel para saudar a Virgem. Além disso, o termo em questão também constitui um sugestivo palíndromo de "Eva", algo evocativo da imagem de Maria como uma nova "mãe" da humanidade. ${ }^{41}$ Embora persistisse nas artes plásticas ao longo do século XVI, a visão de uma entidade sapiente e íntima de sacrossantos mistérios declinaria no final da ldade Média e terminaria por apagar-se no Renascimento. Das polêmicas da Reforma surgiria um outro papagaio que estava relacionado com a América e nada tinha de venerável, não passando de um exótico xerimbabo de luxo ou de um mero bufão malicioso e desprovido de inteligência, capaz de repetir apenas termos de baixo calão, frases soltas e palavras sem nexo - o dito "papaguear". ${ }^{42}$

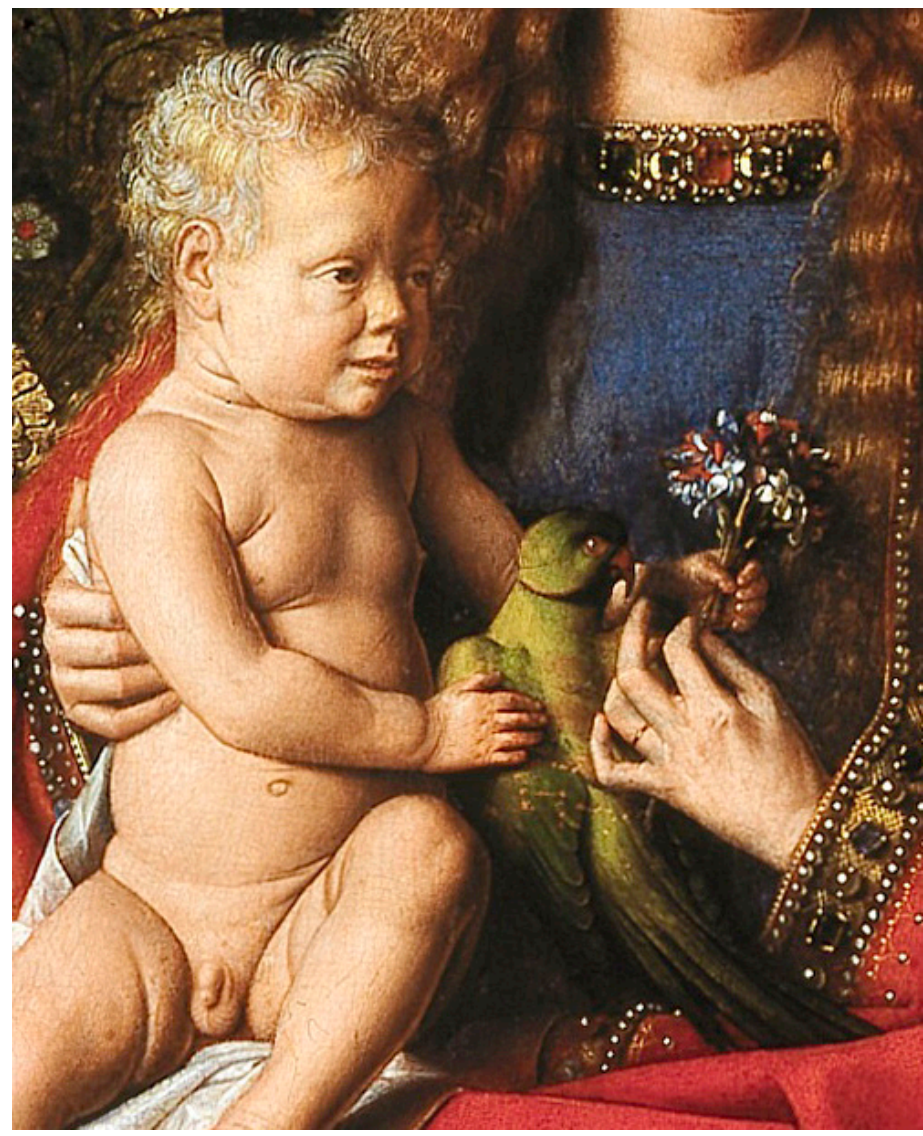

Figura 8 - Detalhe da "Virgem e o Menino com o Cônego van der Paele" de Jan van Eyck (1436), mostrando um periquito-de-colar, $P$ sittacula krameri. Goeningemuseum, Bruges. their ears cut off, in the presence of them that brings the same. III. And be it further enacted, That this Act continue to be and remain in force two years and no longer. Read three times, and ratified in open Assembly, the first day of March, 1700" no original (Cooper, 1837).

35. Vide, por exemplo, Aristóteles (1965-1991), Arriano (1976) e Ctésias (in Photius, 1920, 1959). No entanto, a melhor descrição dessas aves feita por um autor clássico pertence a Apuleio (1866), o qual menciona ser a língua do periquito-de-colar (Psittacula sp.) mais grossa que a das outras aves, o que lhe permitiria mais facilmente articular as palavras, pois também possui um plectro e palato mais largos ("quod eis lingua latior quam ceteris avibus, eo facilius verba bominis articulant patentiore plectro et palato" no original).

36. Estudos feitos com a caturrita, Myiopsitta monacbus, mostraram ser suficiente que a língua se movimente uma fração de milímetro para articular sons tão distintos quanto um "a" ou "o" em inglês (Beckers et al., 2004).

37. Em sua viagem ao Orenoco no início de 1800 , o naturalista alemão Alexandre von Humboldt encontrou vestígios de uma tribo recentemente extinta - os Atures - cujo idioma teria sobrevivido apenas nas palavras ditas por um velho papagaio (Humboldt, 1808, 1814). Além de inspirar um poema de Ernst Curtius, tutor do príncipe Friedrick Wilhelm da Prússia, essa história pungente continuaria sendo muito citada e discutida até os dias de hoje (e.g. Abley, 2003).

38. Pond (2006). Existem registros de periquitos-australianos com um vocabulá- 
rio de mais de 150 palavras (Morozov, 1983).

39. Morozov (1983). Relatos desse tipo seriam mencionados do século XVI ao XVIII, apud Buffon(1780), Gesner (1555), Aldrovandi (15991603), Willughby (1676) e terminariam por consolidar a ideia de "papagaios inteligentes" tantas vezes mencionados por autores do século XIX, como Menault (1868), Wood (1875).

40. Compare Pepperberg (1999) e Saxton (2010).

41. Sobre o significado simbólico dos papagaios nas artes plásticas e literatura, vide Noble (2014), Cohen (2008), Courtney; James (2006), Eisler (1991) e Weber am Bach (2006).

42. Beusterien (2013), Boehrer (2004, 2010), Clark (2006), Cohen (2008), Kalof (2007) e MacMunn (1999).

43. Essas aves muitas vezes constituíam signos da elevada posição social dos mais ricos e poderosos, os quais gostavam de se fazer retratar na companhia de dispendiosas mascotes como macacos e papagaios. Já na primeira metade do século XII, o cardeal Hugues de Saint-Victor lamentava que "apesar de os macacos constituírem os mais vis, sujos e detestáveis animais, os clérigos gostam de mantê-los em suas casas e exibi-los nas janelas para impressionar a turba de passantes com a glória de seus haveres" ("Quae licet vilissimum \& turpissimum \& borrendum sit animal: tamenn bomines seculares suis erroribus decepti, qui in auibus coeli ludunt, \& in bestiis terrae, \& beu maxime clerici in suis domibus banc habent, \& in suis fenestris ponere solent, vt apud stultos qui per transeunt, per eius aspectum gloriam suarum diuitiarum iactirent" no original; Hughes de Saint-Victor, 1648).
Esse novo conceito, entretanto, muitas vezes não bastava para calar as inquietudes despertadas pela existência de papagaios bem-falantes. Ao menos em parte, essa atitude reafirmava o caráter francamente utilitário das relações mantidas entre o Ocidente cristão e o chamado "mundo natural", algo que reduzia a diversidade zoológica a alimento, matéria-prima, inimigos a combater ou bestas subservientes destinadas a executar algum tipo de tarefa. Por vezes interpretado como uma manifestação de soberba ${ }^{43}$ ou de reprovável curiosidade, ${ }^{44}$ qualquer vínculo mais íntimo com os animais também podia despertar suspeitas de práticas animistas ou de pactos demoníacos, sobretudo quando envolvia espécies selvagens ou "pouco usuais". Tolerada em termos da aristocracia e de uma burguesia cada vez mais rica, tal proximidade despertava reações menos lenientes quando praticada pelas classes mais baixas, caso das mulheres acusadas de bruxaria por possuírem bichos de estimação como corvos, lebres e gatos, os quais eram muitas vezes tratados como "familiares" (Figura 9). Presentes durante a "caça às bruxas" - que teve seu apogeu entre 1560 e 1675 -, crenças desse tipo iriam decair no século XVIII, apesar de não terem desaparecido por completo. ${ }^{45}$ Além dos demônios, as próprias feiticeiras poderiam transmutar-se em lobos, lebres, cães, gatos, corvos, corvjas etc., assumindo a forma de morcegos e até mesmo de mariposas quando invadiam as casas em busca do sangue de recém-nascidos. No último quartel do século XVII, Alexandre de Gusmão advertia os pais sobre as bruxas usarem o artifício de se aproximarem das crianças na figura de "gatos, cachorros e outros animais domésticos", motivo pelo qual era necessária "muita vigilância" nos dias anteriores ao batismo. ${ }^{46}$

Acreditava-se que o diabo era capaz de possuir diferentes animais senão todos - e manejá-los ao seu talante, fato consagrado na Bíblia pelo conhecido episódio dos porcos de Gadara descrito nos evangelhos de Mateus (8: 28-34), Marcos (5: 1-20) e Lucas (8: 26-39). Gatos, morcegos, corvos, corujas e sapos não passavam de aliados de Satanás, enquanto ratos, serpentes, caracóis e insetos eram vistos como seres das trevas passíveis de serem combatidos através de variados tipos de exorcismo. ${ }^{47}$ Trata-se de um costume bastante tradicional, pois os antigos camponeses gregos tentavam expulsar os roedores dos campos de cultivo pondo nas pedras uma mensagem escrita, a qual principiava com um esconjuro e terminava com uma ameaça. Um desses textos foi registrado na "Geoponica" - o famoso livro sobre agricultura concluído por volta de 950 A.D. e dedicado ao imperador bizantino Constantino VII Porphyrogenitus. ${ }^{48}$ De certa forma, tais eventos recordam as práticas dos nossos "benzedores de cobras" tidos como capazes de "limpar" os pastos de serpentes à custa de rezas e adjurações. ${ }^{49}$

Os bichos endemoninhados logo apareceriam nas terras descobertas do outro lado do oceano, em parte graças à dificuldade dos europeus em entender a cosmologia dos povos do Novo Mundo. Além de entidades que tinham ou podiam assumir a forma de animais, diversos grupos indígenas também acreditavam na transmigração das almas dos mortos e do espírito dos 


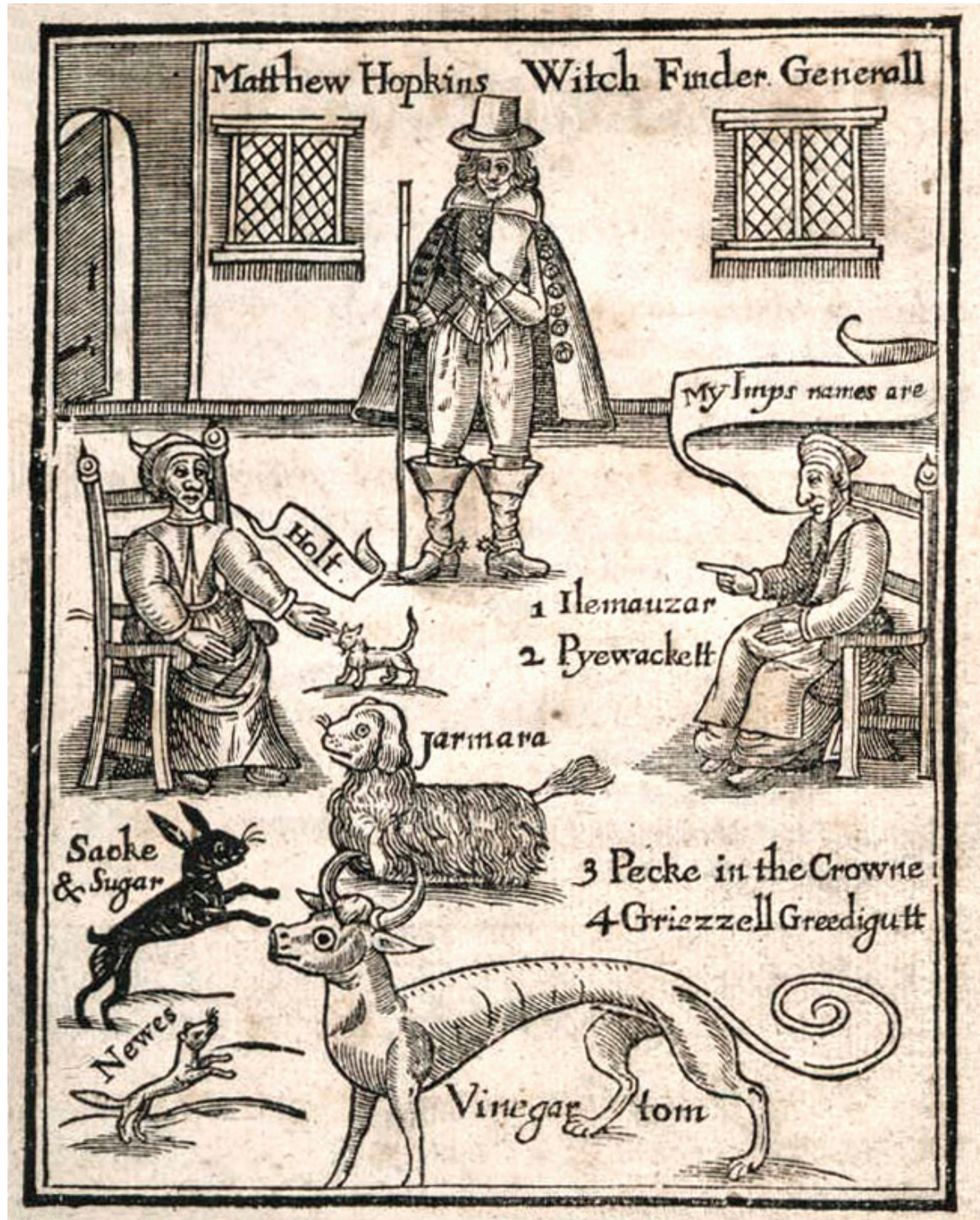

Figura 9 - Bruxas e seus demônios familiares segundo ilustração da "Discovery of Witches" de Matthew Hopkins (1647).

xamãs para o corpo dos mais diferentes representantes da fauna local, universo de relações muito complexas prontamente reduzido a simples "manifestações diabólicas". À guisa de exemplo, vale lembrar o texto da "Crónica del Perú" (1553), na qual Pedro Cieza de León menciona a aparição do diabo na forma de uma "onça feroz", Panthera onca (Linnaeus, 1758), e de um "horrendo urubu", Cathartes aura (Linnaeus, 1758), com a "saliva podre e hedionda",50 enquanto a obra do capuchinho Yves de Evreux sobre o Maranhão (1615) trata de morcegos e "pequenas aves negras" - os já mencionados "familiares" - que transmitiam suas orientações e conselhos aos pajés "com voz humana, falando
44. Estigmatizada como um pecado capital por Santo Agostinho (Confissões, V: 3, 4; X: 35, 55) e outros teólogos, a chamada "curiositas" foi objeto de sérias restrições por parte da Igreja da Idade Média, que caracterizava essa "volúpia por coisas novas" como um desejo quase carnal e uma perigosa afirmação da "soberba do intelecto", em que as desejadas perplexidade e reverência ante os mistérios da Criação eram substituídas por ímpias tentativas de explicar e entender a natureza, muitas vezes feitas à revelia dos textos sagrados. Não surpreende, portanto, o fato de certos renascentistas ocultarem seu afã pelo saber e marcado gosto pelas novidades vindas de terras distantes empregando argumentos tortuosos muitas vezes utilizados pelos próprios religiosos medievais, alegando ser possível louvar e exaltar o Todo-poderoso através do estudo das maravilhas criadas pela graça divina.

45. Familiares seriam os demônios que celebraram algum tipo de pacto para acompanhar e servir uma dada pessoa. Entre as referências existentes na vastíssima bibliografia disponível acerca das bruxas e seus malefícios, vide Guazzo (1608), Hopkins (1647), Kramer; Sprenger (1490), Nynauld (1615) e Prieratis (1575). A história da bruxaria no Ocidente encontra-se resumida por Bechtel (1997), enquanto Bondeson (1999) e Mangin (1872) estudariam as relações entre os animais e o diabo na Idade Média e Renascimento.

46. "Costumam estas bruxas entrar ás creanças em figuras de gatos, cachorros, \& outros domesticos animaes, por isso he necessario, que naquelles dias antes do Bautismo haja nisto muita vigilancia, porque isso he o que o Demonio principal- 
mente pretẽde" no original (Gusmão, 1685). Presente desde os tempos coloniais, tal crença permanecia viva no Brasil e nos países ibéricos até data bastante recente, conforme Cascudo (1954, 1958), Mello e Souza (1986) e José Leite de Vasconcellos (1980).

47. O assunto foi tratado por inúmeros autores, entre os quais Bougeant (1753), Céspedes (1641), Concepcion (1673), Desnoyers (1853), Gascon (1627), Ménabréa (1846) e Remigio (1688). Em termos mais gerais, elucidativas análises sobre a questão foram publicadas por Evans (1906) e Thomas (1971).

48. "Tome um rolo de papiro e escreva o seguinte: 'faço jurar aos ratos aqui presentes que não me causem qualquer prejuízo e tampouco tolerem que outro rato o faça, Eu vos dou aquele campo (dizer qual), mas se eu voltar a surpreendê-los aqui de novo, pela mãe dos deuses, vos irei cortar em sete pedaços'. Escreva isso e coloque o rolo em uma pedra no campo antes do nascer do sol, tendo o cuidado de manter a face escrita para fora" (Bassus, 1781).

49. Cascudo (1956) e Faria; Azevedo (1996).

50. "Se juntaran todos los principales y señores destos valles, y hechos sus sacrificios y cerimonias, les aparecio el diablo (que en su lengua se llama guaca) en figura de Tigre muy fiero [...] Y permitiẽdolo Dios, los demonios en figura \& vnas aues hediondas llamadas Auras [...] le echauã saliua podrida y hedionda" no original (Cieza de León, 1553)

51. "Le Barbier, duquel i'ay parlé cy dessus, retiré dans les plaines de Miary, avoit des Diables familiers souz la figure de petits Oyseaux em tupinambá". ${ }^{51}$ Por conseguinte, haveria uma razoável variedade de "animais demoníacos", elenco composto por mamíferos, aves, répteis, anfíbios, peixes, insetos, aracnídeos e até mesmo "vermes". ${ }^{52}$ Ao contrário do que pretendem certos autores, ${ }^{53}$ as corujas e outras aves noturnas eram particularmente temidas e despertavam pavor por suas vocalizações, enquanto a alma dos mortos encarnaria sobretudo nos papagaios, araras e afins, pois os psitácidas mostrarse-iam "mais próximos ao homem" devido à sua capacidade de falar.

Com efeito, o caso dos papagaios seria agravado pela tradição cristã de só existirem três classes de seres - anjos, homens e demônios - dotados do dom da palavra. Não deve causar surpresa, portanto, que exemplares demasiado loquazes despertassem a séria desconfiança de terem - literalmente - o diabo no corpo, sendo encarados como animais demoníacos ou possuídos. No entanto, a existência de aves com essa habilidade por vezes encontrava justificativa em algo diferente, conforme evidencia a célebre "Navegações de São Brandão", um amálgama de lendas célticas e cristãs do século X. No capítulo referente ao "Paraíso das Aves", São Brandão relata ter chegado a uma ilha povoada de pássaros falantes - na verdade anjos caídos punidos com o castigo menor de serem transformados em aves por não se haverem entregado por completo a Lúcifer. ${ }^{54}$ Tampouco inspira temor a jocosa história do papagaio muito tagarela oferecido a Carlos V de Espanha por Dom João III de Portugal, o qual mantinha o silêncio por não entender o que the perguntavam os castelhanos. ${ }^{55}$ Ainda mais generosa é a fábula relatada pelo monge cisterciense Cesarius de Heisterbach sobre um papagaio que, arrebatado pelas garras de um gavião, evocou seu santo protetor: "Sancte Thoma, adjuva me!" ("Valei-me meu São Tomás!") e foi milagrosamente resgatado. 56 Talvez seja essa a origem do curioso comentário de Alexandre de Gusmão acerca de um piedoso papagaio salvo das "unhas de um gavião" por repetir a Ave Maria. ${ }^{57}$

A ideia de os psitácidas falarem em virtude de uma possessão demoníaca parece remontar pelo menos ao segundo quartel do século XVI, mais ou menos coincidindo com os primeiros momentos da Reforma, pois Martinho Lutero acreditava estar "o diabo nos papagaios e macacos, sendo esse o motivo pelo qual eles podem imitar as pessoas". ${ }^{58}$ Em 1590, Henry Boguet voltaria a abordar essa questão em seu "Discours des Sorciers", 59 enquanto Increase Mather, já na penúltima década do século XVII, divulgaria a história de um papa não especificado que mandou matar seu papagaio por haver recebido uma resposta demasiadamente elaborada a sua pergunta - clara demonstração da presença do maligno ${ }^{60}$ mesmo argumento levantado oitenta anos depois pelo frei Andrés Ferrer de Valdecebro para justificar a crença generalizada em papagaios endemoninhados. ${ }^{61}$ Como os mais supersticiosos ainda fariam o sinal da cruz na presença de aves muito linguarudas na segunda metade do século XVIII, 62 não chega a causar surpresa que, no ano de 1792, um papagaio e um macaco tenham sido processados por heresia e mortos na fogueira em Miranda del Ebro, Espanha. ${ }^{63}$ Desconfianças desse tipo cedo ultrapassariam as fronteiras da Europa, pois já nos 
idos de 1621 circulavam notícias vindas da "Abissínia", atual Etiópia, sobre um papagaio talentoso o bastante para ser levado a juízo sob suspeita de feitiçaria ou possessão por espíritos malignos - e absolvido das acusações. ${ }^{64}$

Conforme seria de esperar, os papagaios demoníacos logo seriam assinalados no Novo Mundo. Entre 1554 e 1555, relata o "inca" Garcilazo de la Vega, havia um papagaio em Potosí capaz de declinar a nação e a província de todos os transeuntes, desmascarando até mesmo a tentativa feita por uma bela índia de passar-se por alguém de sangue real, sendo acusado de diabólico por tal perspicácia. ${ }^{65}$ Por volta de 1681, Satã apareceria para o dominicano Juan Meléndez como uma arara, ${ }^{66}$ a encarnação preferida do demônio em terras americanas segundo o jesuíta Andrés de Zárate. ${ }^{67}$ No final do século XVIII, o frei Juan de Santa Gertudris lembraria ter encontrado em Santa Rosa, atual Honda, Colômbia, um papagaio tão habilidoso que um dos seus confrades, irritado com seus impagáveis arremedos, terminaria por acusá-lo de estar possesso. ${ }^{68}$

No Brasil, os supostos animais demoníacos marcariam presença já em meados do século XVI, a julgar por dois episódios envolvendo o padre Joseph de Anchieta. No primeiro deles, datado de 25 de julho de 1567, os jesuítas Inácio de Azevedo, Manoel da Nóbrega, Luis da Grã e Anchieta foram impedidos de rezar missa em Bertioga por uma maléfica baleia que atacou o batel no qual iam para a praia ao ponto de quase despedaçá-lo, até sua fúria ser milagrosamente contida pela mão de Deus e o animal afastar-se mansamente. 69 Vinte anos mais tarde, em plena Baía de Guanabara, Anchieta iria conjurar um grupo de cetáceos ameaçadores surgidos em torno de sua canoa. ${ }^{70}$ Por outro lado, tampouco faltavam psitácidas assaz loquazes, como exemplifica o divertido relato de Jean de Léry sobre um papagaio maravilhoso que "parecia entender sua dona". Em troca de um pente ou espelho, ela fazia seu xerimbabo saltar, assoviar e emitir o brado de guerra da tribo, pois ao receber a ordem de dançar ele dançava e de cantar ele cantava. Com fina ironia, a proprietária admitiu ceder essa ave tão espetacular apenas por uma peça de artilharia, ou seja, algo completamente fora de questão. ${ }^{71}$

caso mais notável, contudo, teria ocorrido no nordeste do Brasil durante o período do domínio holandês, tendo como protagonista o próprio conde Johan Maurits van Nassau-Siegen. Transpondo nossas fronteiras, a inusitada habilidade dessa "ave demoníaca" em formular perguntas e dar respostas "tão acertadas como se fosse uma criatura racional" acabaria por se converter em uma história célebre na Europa seiscentista, tendo sido mencionada inclusive no "Essay concerning Humane Understanding" de John Locke (1690). Na verdade, o célebre filósofo inglês apenas reproduziria o trecho das "Memoirs" de William Temple (1689),72 o qual se refere a um diálogo mantido com Johan Maurits van NassauSiegen, nos seguintes termos:

Eu desejava saber do próprio príncipe Maurits van Nassau o que havia de verdadeiro em uma história que várias vezes haviam contado acerca de um papagaio que o príncipe possuiu durante seu governo do Brasil. Dizia-se que esse papagaio interrogava e dava respostas tão acertadas como se fora uma criatura racional, pelo que se acreditava, na casa do prínci- noirs, lesquels l'advertis-soient des choses qu'il devoit faire, \& d'autres qui se passoient soit en l'Isle, soit en autre lieu [...] Celuy du costé de Thion meschant $\&$ mal-heureux (qui n'a iamais voulu venir en l'Isle, ains detournoit, tant qu'il pouvoit, ses semblables d'y venir) nourrissoit une Chauve-soury dans sa loge, qu'ils appellent Endura, laquelle parloit à luy d'une voix humaine en Topinambos, \& si haut quelquefois qu'on la pouvoit entendre à six pas de la loge, non distinctement, ains confusement $\&$ d'un son enfantin: Le Sauvage luy respondoit demeurant seul en sa loge: car quand il s'appercevoit qu'elle vouloit parler à luy, il faisoit sortir ses gens" no original (Yves d'Evreux, 1615).

52. Karsten (1926).

53. Por exemplo, Sick (1985).

54. "We survive from the great destruction of the ancient enemy, but we were not associated with them through any sin of ours. When we were created, Lucifer's fall and that of his followers brought about our destruction also. But our God is just and true. In his great judgment he sent us here", O'Donoghue (1893), O'Meara (1976). Uma interessante reflexão sobre o problema dos animais falantes é feita por Sáez (2011).

55. "El Rey dom Ioão terceiro, falando com dom Anrique [...] lhe contou que elle mandara ao emperador Carlos quinto, hum papagayo que falaua \& respondia a preposito, o passaro vendo se entre gente que não conhecia, por mais que o Emperador lhe perguntaua, a nada respondia, mandou chamar o homem que lho leuara, \& disse el Rey meu senhor me escreveo marauilhas deste papagayo, pergunta lhe qual he a razão porque não falla: Ioão fer- 
nandes (que assi se chamaua o homem que o leuou) the perguntou qual era a causa porque diante de sua Magestade não falaua, a que o papagayo respondeo, Ioão Fernandes não me entendo com esta gente" no original (Ferreira, 1616).

56. Esta curiosa história pertence ao "Dialogus miraculorum", uma coletânea de 746 milagres escrita entre 1219 e 1223 (vide Cesarius de Heisterbach, 1851). Segundo o frei Andrés Ferrer de Valdecebro (1670), o gavião teria sido fulminado, deixando livre e vivo o papagaio ("cayendo muerto el Gavilán, dexando libre, e vivo al papagayo"). Essa passagem também seria mencionada em outras oportunidades (e.g. Howe, 1912 e Sabatier, 1897).

57. "De hum Papagayo se conta, que repetia o Credo de todo sem errar. E de outro que dizia a oraçam da Ave Maria, que em occasiam de perigo, \& que o Gaviam o levava nas unhas, lhe servio de defença" (Gusmão, 1685). Lembramos que papagaios religiosos também aparecem no folclore brasileiro, tendo sido imortalizados nas "Histórias de Alexandre", de Ramos (1944).

58. "Ich glaube, in den Sittichen oder Papageien, Affen und Meerkatzen steckt der Teufel, weil sie die Menschen so nachahmen können". Tal assertiva pertence à chamada "Tischreden", uma coletânea baseada nas notas tomadas por diversos estudantes de Lutero entre 1531 e 1544 (Lutero, 1912-1921).

59. "Ce qui me faict croire encores que le diable estant entré dans le corp d'vn chien, d'vn bouc, d'vn oiseau, ou de quelque autre beste peut contrefaire la voix d'vn homme, comm'il l'a contrefaict aussi souuentes fois au raport de la plus pe, que o tal papagaio andava possesso. Acrescentava-se que um dos capelães do príncipe tomara tamanha aversão aos papagaios, por causa daquele, que não podia suportá-los, dizendo que eles tinham o diabo no corpo. Ouvi referir todas essas circunstâncias e muitas outras que me asseguravam serem verdadeiras, e isto me levou a rogar ao príncipe que me dissesse o que de verdadeiro havia em tudo isso. Respondeu-me ele com sua costumeira franqueza e em poucas palavras que havia alguma coisa de real, mas que a maior parte do que me haviam contado era falso. E então contou-me que, quando chegou ao Brasil, ouviu falar nesse papagaio e, conquanto supusesse que nada de real havia na história, teve a curiosidade de o mandar vir, apesar de achar-se o papagaio muito longe do lugar onde o príncipe residia. $\bigcirc$ pássaro era muito velho e muito gordo. Quando entrou na sala, onde se achava o príncipe acompanhado de vários holandeses, e mal os viu, foi dizendo "que reunião de homens brancos é essa?" Alguém the mostrou o príncipe, perguntando "quem ele era?" $\bigcirc$ papagaio respondeu que "era um general". Aproximaram-no do príncipe e este the perguntou: "de onde vens?". $\bigcirc$ papagaio: "do Maranhão". $\bigcirc$ príncipe: "a quem pertences?". ○ papagaio: "a um português". $\bigcirc$ príncipe: "o que fazias lá?". $\bigcirc$ papagaio: "guardo galinhas". $\bigcirc$ príncipe - rindo-se: "guardas galinhas?". $\bigcirc$ papagaio: "sim, eu bem sei fazer chuc chuc ...", como se costuma fazer quando se chamam as galinhas, o que o papagaio repetiu várias vezes. Repito as palavras desse interessante diálogo em francês, como o príncipe m'as transmitiu. Perguntando-the eu em que língua falava o papagaio, disse-me que em "brasiliense". Perguntei-the também se ele entendia essa língua, respondeu-me que não, mas que teve o cuidado de fazer vir dois intérpretes, um brasileiro que falava holandês e outro holandês que falava "brasiliense", 73 que os interrogara em separado e que ambos reproduziram as mesmas frases. Não omiti essa história, porque ela é extremamente singular e curiosa, e pode passar por certa. Ouso dizer que pelo menos o príncipe acreditava no que me dizia e que ele sempre passou por um homem de bem e de honra. Deixo aos naturalistas o cuidado de raciocinar sobre esse caso, e aos outros homens a liberdade de pensar a tal respeito o que bem thes aprouver. Seja como for, não é talvez de mau gosto distrair o público com tais digressões, venham ou não a propósito. ${ }^{74}$

Vale destacar existir uma pintura desse papagaio - um exemplar de Amazona aestiva - nos chamados "Libri Principis", ilustração esta acompanhada de uma nota do punho do próprio Nassau dizendo: "Este é o papagaio que tão habilmente responde e formula perguntas que muitas centenas de pessoas que o ouviram nada mais puderam concluir senão que era o demônio que falava através dele. Comigo não viveu mais de 14 dias. Quando morreu, estava tão duro quanto um pedaço de pau" (Figura 10). ${ }^{75}$

Uma versão dessa história ainda circula em Pernambuco graças à cultura oral, pois os moradores de Goiana contam que - no tempo dos holandeses alguns habitantes teriam ensinado o hino batavo a um papagaio. Como o desempenho dessa ave era dos mais impressionantes, decidiram mandá-lo como presente ao "rei da Holanda". Sua Majestade, porém, nunca tinha visto semelhante criatura e cortou-the a cabeça logo no começo da cantoria, pois um animal falante só podia ser algo demoníaco.76

No Brasil, os relatos sobre os papagaios possessos sobreviveriam pelo menos até o penúltimo quartel do século XVIII, conforme demonstra o "Tesouro descoberto no rio Amazonas", obra do jesuíta João Daniel escrita entre 1757 e 1776. $\bigcirc$ texto distingue quatro espécies de papagaio que 


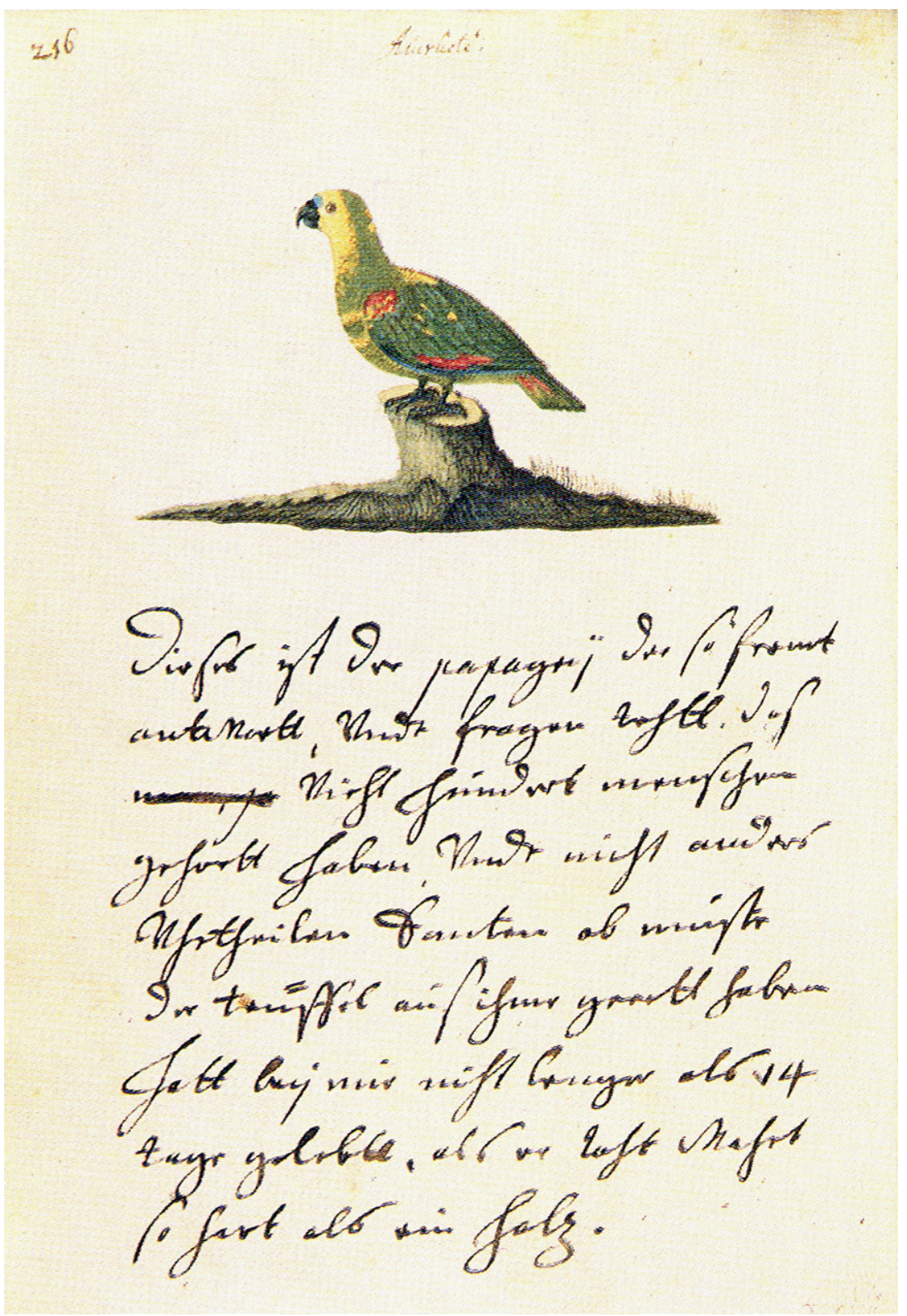

Figura 10 - $\bigcirc$ "papagaio demoníaco", Amazona aestiva, de Johan Maurits van Nassau-Siegen segundo pintura dos "Libri Principis" (1633-1644). Biblioteka Jagiellońska, Cracóvia.

aprendem bem a falar, como já disse, ainda que umas com maior facilidade que outras: têm a língua bem expedita e enquanto são pequenos aprendem quanto ouvem, e por isso costumam tirá-los do ninho e criá-los em casa para os ensinar na menor idade; porque papagaio velho já não toma língua, digo aprende língua. Pelo que com muita propriedade são reputados por símbolo dos pecadores, que vivendo sempre nos seus vícios, guardam para a velhice as lições de bom católico, e os bons preparos para a morte, sem temerem que lhes suceda o 
was about the size of a hen. He had been taught to talk in Indian, Portuguese, and Arabic, and could speak the king's name almost as plainly as a man. Among other strange things which he was in the habit of doing, he would neigh like a horse, and imitate the mewing of a cat so exactly that nobody could tell the difference, unless he saw the parrot making the noise. He was such a wise bird, that his master was summoned to appear with him before the assembly of judges, so that they might find out the cause of these remarkable talents. In that age of the world, you know, the belief in witchcraft was very common in many parts of the world; and some of the Abyssinians thought that this parrot's skill in imitating sounds so exactly was in some way to be traced to the agency of evil spirits. The judges acquitted the bird, however" no original (Woodworth, 1851). A mesma passagem seria posteriormente reproduzida por outras fontes (e.g. Anônimo, 1870).

65. "En Potocsi por los años de mil y quinientos y cincuẽta y quatro, y cincuenta y cinco, huuo vn Papagayo de los que llaman Loro, tan hablador, que a los Yndios é Yndias que passauan por la calle, les llamaua por sus prouincias a cada vno de la nascion que era, sin errar alguna: diziendo Colla Yunca, Huayru Quechua, \&c. como que tuuiera noticia de las diferencias de tocados, que los Yndios en tiempo de los Incas trayan en las cabeças para ser conocidos. Vn dia de aquellos passó vna Yndia hermosa por la calle, do el Papagayo estaua, yua con tres o quatro criadas, haziendo mucho de la Señora Palla que son las de la sangre real. En viéndola el Papagayo dio grandes gritos de risa diziendo Huayru, Huayru, Huayru, ̃̃ es vna nasciõ de gente mas vil y mesmo que aos papagaios velhos, que só são bons para o espeto, e é bem gostosa sua carne. Porém, enquanto são pequenos, não só aprendem bem a falar, e cantar, mas também a rir e a chorar; e a arremedar aos animais, e tanto as vezes falam que se fazem suspeitos de que nele fala o diabo; porque são tão aporité ou a ponto, e congruentes as suas respostas, que parecem exceder o seu instinto, por mais que alguns queiram meter nos cascos dos outros que eles, e outros animais tem juízo, e verdadeiro discurso mais ou menos expedito. Em uma missão se criou, e estava um, que respondia ad rem em tudo o que se the perguntava, como se tivesse juízo. Vinha algum hóspede a casa, respondia o papagaio, o dono está ocupado, ou, não está em casa, ou, está dormindo etc. Ausentava-se algumas vezes de casa, e depois de alguns dias tornava acompanhado de outros bravos, e perguntando-lhe, aonde foste papagaio? Fui buscar a estes meus parentes repunha. Além desta, dava outras respostas tão galantes, e a propósito, que o mesmo dono desconfiava dele e o queria matar; mas o bom do papagaio, como se advertisse, se retirava e andava tão precatado que já não queria vir à mão ou dar o pé, como costumam [...] Em outra Missão havia outro que também adivinhava e predisse algumas coisas bem contingentes, como vendo vir algum em alguma embarcação, dizia da cumeeira o papagaio - Lá vem um branco - outras vezes dizia - traz papel -, isto é carta da cidade, e cousas semelhantes. Verdade seja que este segundo podia dizer isto materialmente maxime por ouvir aos rapazes, e índios, que assim costumavam falar quando chega, ou vem vir alguma canoa, ou branco, mas o primeiro e outros semelhantes dão grande suspeita de que eles não falam sós. ${ }^{77}$

Discussão

Passado o período colonial, os Psittacidae continuariam a representar um problema para a agricultura, algo observado em várias partes do Novo Mundo segundo o testemunho de naturalistas como Charles Darwin. ${ }^{78}$ No caso da América do Norte, tal realidade muito contribuiria para a extinção do periquito-da-carolina, Conuropsis carolinensis (Linnaeus, 1758), único representante do grupo nativo dos Estados Unidos (Figura 1 1). Nas palavras do ornitólogo John James Audubon, essa espécie consumia ou destruía qualquer tipo de fruta indiscriminadamente, sendo um visitante sempre indesejável capaz de cobrir os campos com um tapete colorido e devastar duas vezes mais grãos que os necessários para satisfazer seu apetite. Abriam maçãs e peras em busca de sementes e desprezavam aquelas muito verdes, logo passando para a seguinte até deixar a árvore nua. Eram mortos em quantidade, de oito a vinte a cada descarga de arma de fogo, mas os sobreviventes voltavam até estarem reduzidos ao ponto de não compensar o gasto de mais munição, pois várias centenas de exemplares podiam ser abatidos em poucas horas. ${ }^{79}$ Ocorrendo desde a Nova Inglaterra e Wisconsin até o Tennessee, Kentucky e Golfo do México, o periquito-da-carolina parece ter sofrido um rápido declínio, pois já se encontrava restrito à Flórida no final do século XIX. $\bigcirc$ último registro na natureza data de 1904 e o derradeiro exemplar em cativeiro sobreviveria até fevereiro de 1918 no jardim Zoológico de Cincinatti. ${ }^{80}$ Nesse mesmo período, tampouco faltariam notícias no Brasil sobre ataques a pomares, plantações de arroz e milharais efetuados por papagaios, tiribas, tuins, jandaias, maracanãs, periquitos 
e pelas onipresentes caturritas, as quais constituíam ameaça suficiente para instigar - governo do Rio Grande do Sul - pelo menos até 1920 - a adquirir cada bico de Psittacidae apresentado por uma pequena quantia. ${ }^{81}$ Iniciativas do gênero continuariam sendo aplicadas para o controle de outras espécies consideradas daninhas, caso dos biguás, Phalacrocorax brasilianus (Gmelin, 1789), que quase levariam à falência o importante comércio de bagres salgados estabelecido na cidade de Laguna, litoral de Santa Catarina, no primeiro quartel do século XX. ${ }^{82}$

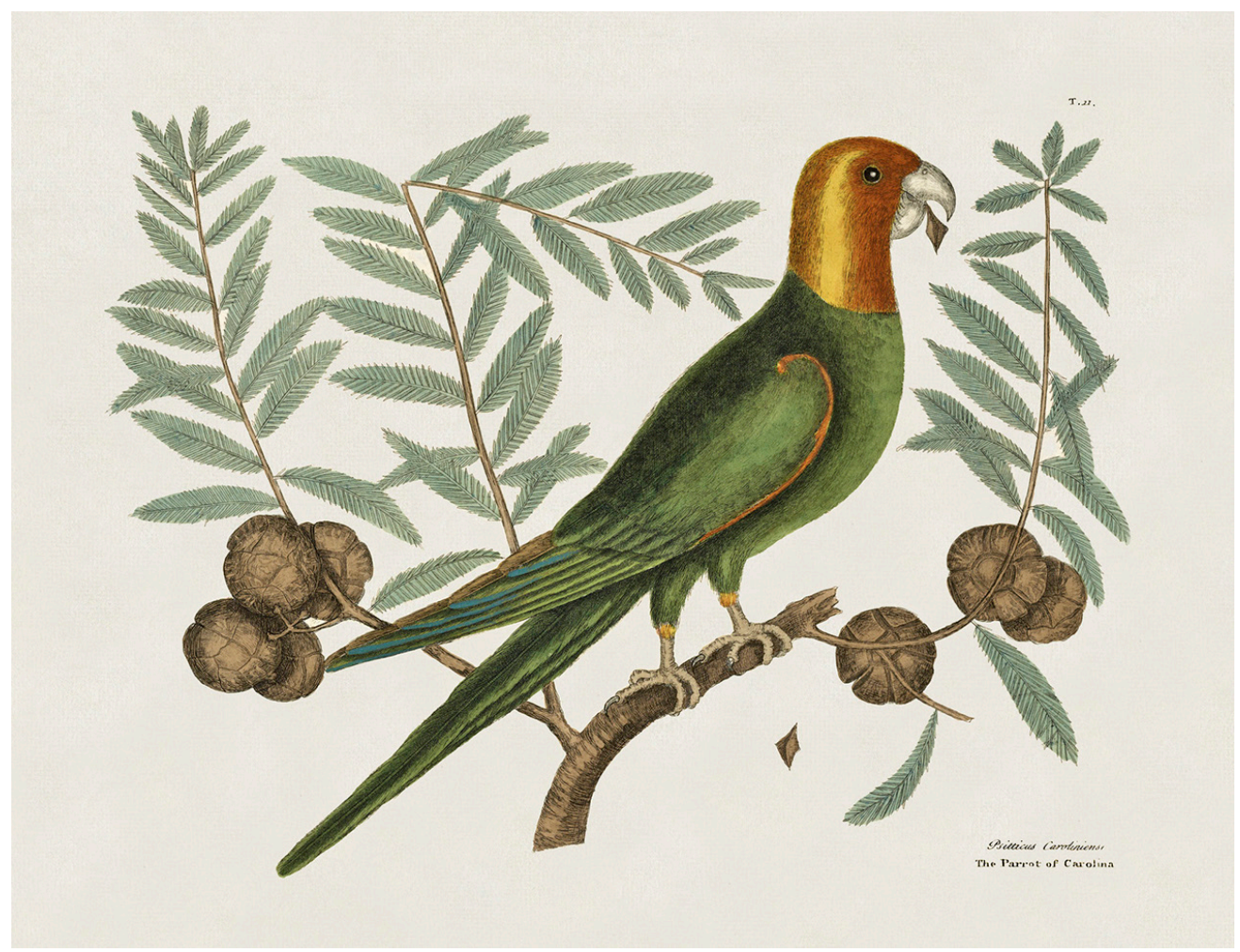

Figura 11 - Periquito-da-carolina, Conuropsis carolinensis, segundo a "Natural History of Carolina, Florida and the Bahama Islands" de Mark Catesby (1729-1747).

Apesar de todas as evidências históricas, existe uma tendência recente de considerar as notícias sobre as devastações promovidas pelos psitácidas como um exagero dos fazendeiros prejudicados, opinião que busca atenuar a ameaça representada por essas aves para o cultivo de cereais e frutas em diferentes partes do mundo. Todavia, certas pesquisas parecem mostrar justo o contrário, revelando haver lavradores com uma ideia bastante exata dos prejuízos causados. ${ }^{83}$ De qualquer forma, os papagaios, jandaias e afins ocupam uma posição de destaque entre os vertebrados citados como praga no continente americano, sendo superados apenas pelos roedores de pequeno porte em pelo menos 16 países (México, El tenida en menos q̃ otras. La Yndia passó auergonçada, por los que estauan delante, que siẽpre auia vna gran quadrilla de Yndios escuchando el paxaro: y quando llegò cerca escupiò hazia el Papagayo, y le llamó Cupay, que es diablo. Los Yndios dixeron lo mismo, porque conoscio la Yndia con yr disfraçada en abito de Palla" no original (Vega, 1609).

66. "Vio vna Huacamaya comiendo vn pollo [...] y causòle admiracion ver cosa em aquella que, que fuesse contra su natural, porque nunca come carne. Iunto della estaua vn idolo de palo, de mayor estatura, que vn hombre, y tenia a los pies vna piedra llana muy ensangrentada. En donde supo, que todas las semanas sacrificauan vn mancebo, que passasse de catorze años, y tuuiesse malicia para pecar" no original (Meléndez, 1681).

67. "Em figura de Guacamaya" no original (Zárate in Francismar Alex Lopes de Carvalho, 2015).

68. "Había juntamente en Santa Rosa un loro tan hablador que no he visto otro semejante jamás; y remedaba con tal gracia cuanto oía, que el Padre Urrea, viendo que a pocos días remedaba ya cuanto nosotros hablábamos, lo odió y decía: Este loro tiene algún demonio en el cuerpo" (Santa Gertrudis, 1994).

69. "Partio o Padre Ignacio de Azeuedo de S. Vicente no mes de Iulho do presente auno de 1567 em companhia do mesmo Bispo Dom Pedro Leitão, \& dos Padres Prouincial, Nobrega e Ioseph de Anchieta: \& nesta viagem acõteceo a estes companheiros hum caso milagroso de protecção da mão diuina. Foi ancorar a embarcaçaõ defronte do porto a que chamamos Britióga, por falta de ventos: era vespora do Apostolo 
Santiago, quiseraõ os padres ir dizer Missa a terra, meteraõse em o batel o Padre Ignacio, Gram, Nobrega \& Ioseph, com outros passageiros: ex que chegando no meio do caminho, leuantase hũa grande baleia (se naõ dissermos serpente infernal) assanhada, ao que pareceo, de algũas frechadas que lhe tiraraõ do nauio, ou dolorida de algum filho que perdera: como quer que fosse, ela leuantando a cabeça medonha, \& parte do corpo sobre a agoa, foi seguindo apos o batel, horrenda, leuando diante de si montes de agoa, \& batẽdo as azas com tão disformes gestos, que todos se deraõ por perdidos: \& com mais euidencia, quando chegãdo jà ao batel, meteo a cabeça de baixo, \& jũtamente leuantou a cauda sobre elle, como pera descarregar a pancada. Aqui se prostràrão todos de joelhos, \& cõ as mãos ao Ceo leuantadas, em termos de morrer, alagado já o batel com agoa, pedião a Deos misericordia; \& junto com elles o Bispo, \& os mais do nauio, que os estauão vendo. Não permittio porèm o Ceo q̃ acabassem desastradamente tão grandes e importãtes seruos seus; porque aquelle monstro marinho, como mandado por um poder occulto, ou qual se obedecéra ás mãos leuantadas ao Ceo, parou com o golpe da cauda, \& se foi escoando por proa, deixando o batel fóra de affliçoens, posto qui quase alagado" no original (Simão de Vasconcellos, 1663).

70. "Vinha de S. Lourenço pera a Cidade com algũs companheiros, acharam no meio da trauessa do mar, que he distancia de huma legoa, cardumes de Baleas, que alli costumam entrar a parir; em tanta quantidade que os remeiros da canoa, nam sabiam pera que parte hauiam de remar, porque dee todas se viam cercados com perigo euidente de en-
Salvador, Nicarágua, Costa Rica, Panamá, Haiti, Trinidad, Colômbia, Venezuela, Suriname, Equador, Peru, Brasil, Paraguai, Uruguai e Argentina). A menção de algumas espécies é recorrente e as campanhas de combate, como seria de esperar, mostrar-se-iam capazes de contribuir de forma significativa para reduzir os contingentes de determinados representantes, tendo ajudado a promover a virtual extinção do maracanã, Primolius maracana, na Argentina e o patente declínio do papagaio-barranqueiro, Cyanoliseus patagonus, no Chile. ${ }^{84}$ No Rio Grande do Sul, o papagaio-charão, Amazona pretrei (Temminck, 1830), teve sua população estimada em 16.900 indivíduos no ano de 2001, mas já foi numeroso ao ponto de compor bandos de várias centenas ou mesmo de mil exemplares no final do século XIX, chegando a integrar a lista de aves prejudiciais para a agricultura local em 1979.85

Os pequenos fazendeiros da Reserva Nacional Pacaya-samiria, Peru, encaram duas maitacas, Aratinga leucophthalma e Aratinga weddellii, e o maracanã-guaçu, Ara severa, como os maiores inimigos dos milharais, acumulando perdas médias de $11,63 \%$ ou 30,16\% conforme se leve em conta apenas o milho comido ou o total de espigas danificadas. Além de abater a tiros ou envenenar um número não determinado de exemplares, os habitantes da região empregariam redes de pesca para defender as plantações, chegando a capturar nada menos de 2.031 aves em um único ano, contingente formado por 933 Aratinga weddelli, 832 Aratinga leucophthalma e 266 Ara severa. ${ }^{86}$ Já os lavradores amazonenses da Reserva de Desenvolvimento Sustentável Amanã consideram o papa-cacau, Amazona festiva (Linnaeus, 1758), como a maior ameaça para a agricultura tradicional, apesar de outros psitácidas também causarem depredações. Seriam afetados o açaí, a banana, a bacaba e sobretudo a pupunha, pois $71,9 \%$ dos plantadores dessa palmeira tiveram a produção reduzida em $50 \%$ ou mais, prejuízo que levaria ao abate de 357 papa-cacaus, 96 curicas e 16 araras no período de um ano. ${ }^{87}$ Muito embora a pequena agricultura familiar com baixa tecnologia agregada e as plantações situadas nas fronteiras agrícolas pareçam ser realmente mais vulneráveis aos ataques, cumpre lembrar que há espécies de Psittacidae com capacidade de assolar grandes cultivos, caso bem exemplificado pela caturrita, Myiopsitta monachus. No sul do Brasil, Uruguai e Argentina, essa ave é considerada a pior das pragas agrícolas, pois ocasiona estragos consideráveis na produção de cítricos e de grãos, em particular o milho e o girassol, diminuindo o rendimento esperado em até $45 \% .88$

De fácil adaptação, a caturrita também ocasiona problemas em linhas elétricas ao construir seus maciços ninhos de gravetos nas torres de transmissão, além de estar cada vez mais presente em áreas urbanas. A mesma plasticidade pode ser observada em outros representantes, como a ararinha, Diopsittaca nobilis (Linnaeus, 1758), o periquito-verde, Brotogeris tirica, e a araguaí, Aratinga leucophthalma, os quais vêm colonizando com sucesso várias cidades, tornandose muito comuns até mesmo em metrópoles como Rio de Janeiro e São Paulo. Além de devastarem pomares suburbanos, tais psitácidas não só destroem o 
madeiramento das casas como roem cabos elétricos e de telefone, provocando curtos-circuitos e interrupções capazes de durar horas a fio em diversas localidades de São Paulo e Minas Gerais. ${ }^{89}$

A exemplo do caso anterior, tampouco os "papagaios demoníacos" desapareceram do mundo contemporâneo, tendo marcado seu retorno após décadas de aparente silêncio. Mesmo considerando o fundamentalismo religioso tão presente nos dias de hoje, afigura-se bastante insólito o fato de psitácidas muito loquazes, agressivos ou com comportamento fora do usual serem encarados como exemplos de metempsicose ou possessão, chegando mesmo a atrair exorcismos. ${ }^{90}$ Trata-se, contudo, de uma posição assaz minoritária, pois a esmagadora maioria continua a ver com bons olhos os papagaios e afins como bichos engraçados e maliciosamente espertos, valorizando bastante sua faculdade de imitar a voz humana. Mesmo na época colonial, as múltiplas estratégias utilizadas para ensinar os papagaios a falar não parecem ter sido objeto de suspeita, enquanto na atualidade existem várias publicações dedicadas ao ensino das diferentes práticas utilizadas para esse fim. ${ }^{91}$ Por vezes, treinar papagaios se transformaria em uma profissão, conforme evidencia o delicioso anúncio de uma respeitável viúva publicado no jornal inglês "The Spectator" a 11 de abril de 1711 . Abalada pelos azares da fortuna, essa senhora dispunha-se a ensinar todas as espécies de aves faladoras, como papagaios, estorninhos e pegas, a imitar a voz humana com grande perfeição, levando-as não só a pronunciar as palavras com a tonalidade e acento apropriados, mas a usar todas as frases e cumprimentos elegantes usados nos salões de chá e recepções. Como a "educação ministrada a essas inocentes criaturas" frequentemente mostravase assaz indecorosa, os papagaios seriam acomodados em quartos situados longe da rua onde - "para a ofensa dos ouvidos delicados e castos" - eles aprendiam grosserias, canções obscenas e indecentes, expressões de passantes e desocupados, além dos gritos de gente como peixeiros e jogadores. ${ }^{92}$

Várias décadas mais tarde, já no primeiro quartel do século XX, um habitante de Hamburgo usaria seu domínio das línguas para treinar papagaios em alemão, francês, italiano, espanhol e inglês. Essas aves eram negociadas com diversos países da Europa e custavam - no câmbio da época - entre 600 e 6.000 réis conforme sua habilidade, apesar de uma ter sido vendida por 6.400 réis a "uma princesa de Wiesbaden". Não era difícil

entrar em qualquer negócio em Hamburgo e sentir baixar do alto a voz [de um papagaio] exaltando e recomendando a compra de um artigo especial: "as nossas calças de casimira são as melhores do mundo", "compre esse pano", "as nossas cores não desbotam". Embora caro, tal recurso dava excelentes resultados, sobretudo porque as senhoras apreciavam muito a originalidade do vendedor. ${ }^{93}$

No ano de 1907, a firma portenha "Echegaray Hermanos y Cia" buscaria o mesmo objetivo ao anunciar a bela recompensa de 500 pesos para quem apresentasse um papagaio que falasse "cabreiroa", sua marca de água mineral (Figura 12). contrar algumas dellas. Porem Ioseph, como já outra vez vindo de $\mathrm{S}$. Vicente, leuantouse donde vinha assentado, lançou huma bẽçam aos peixes indomitos, \& foram vistos logo encontinente margulhar, \& irem ao fundo" no original (Simão de Vasconcellos, 1672).

71. "Mais c'estoit bien encor plus grand' merueille d'vn perroquet de ceste espece, lequel vne femme sauuage auoit apprins en vn village à deux lieues de nostre isle : car comme si cest oiseau eust eu entendement pour comprendre \& distinguer ce que celle qui l'auoit nourri lui disoit: quand nous passions par là, elle nous disant en son langage, Me voulez-vous donner vn peigne ou vn miroir, \& ie seray tout maintenant en vostre presence chanter \& danser mon Perroquet? si la dessus pour en auoir le passetemps, nous luy baillions ce qu'elle demandoit, incontinent qu'elle auoit parlé à cest oyseau, non seulement il se prenoit à sauteler sur la perche où il estoit , mais aussi à causer, siffler \& à contrefaire les sauuages quand ils vont en guerre, d'vne façon incroyable: bref, quand bom sembloit à sa maistresse de lui dire, Chante, il chãtoit, \& Danse, il dansoit [...] ceste femme sauuage l'appelant son Cherimbaué, c'est à dire, chose que l'aime bien, le tenoit si cher que quand nous le lui demãdions à vendre, \& que c'est qu'elle en vou loit, elle respõdoit par moquerie, Moca-ouassou, c'est à dire, vne artillerie: tellement que nous ne le sceusmes iamais auoir d'elle" no original (Lery, 1578).

72. Locke (1690), Temple (1689). Graças ao livro do filósofo inglês, essa história terminaria sendo repetida inúmeras vezes por diversos autores (e.g. Johnson, 2011, Anônimo, 1870, Woodworth, 1851) 
73. Ou seja, um indígena que falava holandês e um holandês que falava tupi.

74. "I had a Mind to know from his own Mouth, the Account of a common, but much credited Story, that I had heard so often from many others, of an old Parrot he had in Brasil, during his Government there, that spoke, and ask'd and answer'd common Questions like a Reasonable Creature; so that those of his Train there generally concluded it to be Witchery or Possession, and one of his Chaplains, who liv'd long afterwards in Holland, wou'd never from that Time endure a Parrot, but said they all had a Devil in them. I had heard many Particulars of this Story, and assever'd by People hard to be discredited, which made me ask Prince Maurice what there was in it he said, with his usual Plainness, and Dryness in Talk, There was something true, but a great deal false, of what had been reported. I desir'd to know of him what there was of the First? he told me short and coldly, That he had heard of such an old Parrot when he came to Brasil; and tho' he believ'd nothing of it, and 'twas a good Way off, yet he had so much Curiosity as to send for it; That 'twas a very large, and a very old one; and when it came first into the Room where the Prince was, with a great many Dutchmen about him, it said presently, What a Company of White Men are bere? They ask'd what he thought that Man was? pointing at the Prince. It answer'd, Some General or other. When they brought it close to him, he ask'd it, D'ou venez, vous? [Whence come you?] It answer'd, De Maragnan [From Maragnan]. The Prince, $A q u i$ estez vous? [To whom do you belong?] The Parrot, $A$ un Portugais, [To a Portugueze]. The Prince, Que fais tu là? [What do you there?]
Com o avanço da tecnologia, principiariam as tentativas, nos Estados Unidos e na Europa, de adestrar papagaios por meio de um fonógrafo (Figura 13). Segundo reportagem publicada na "Strand Magazine" de 1903, certo J. Hope teria fundado uma "escola fonográfica para papagaios" na Filadélfia, instituição reputada por seu criador como única no mundo. $\bigcirc$ preço do curso completo de seis meses era de oito libras - ou dez xelins semanais no caso de

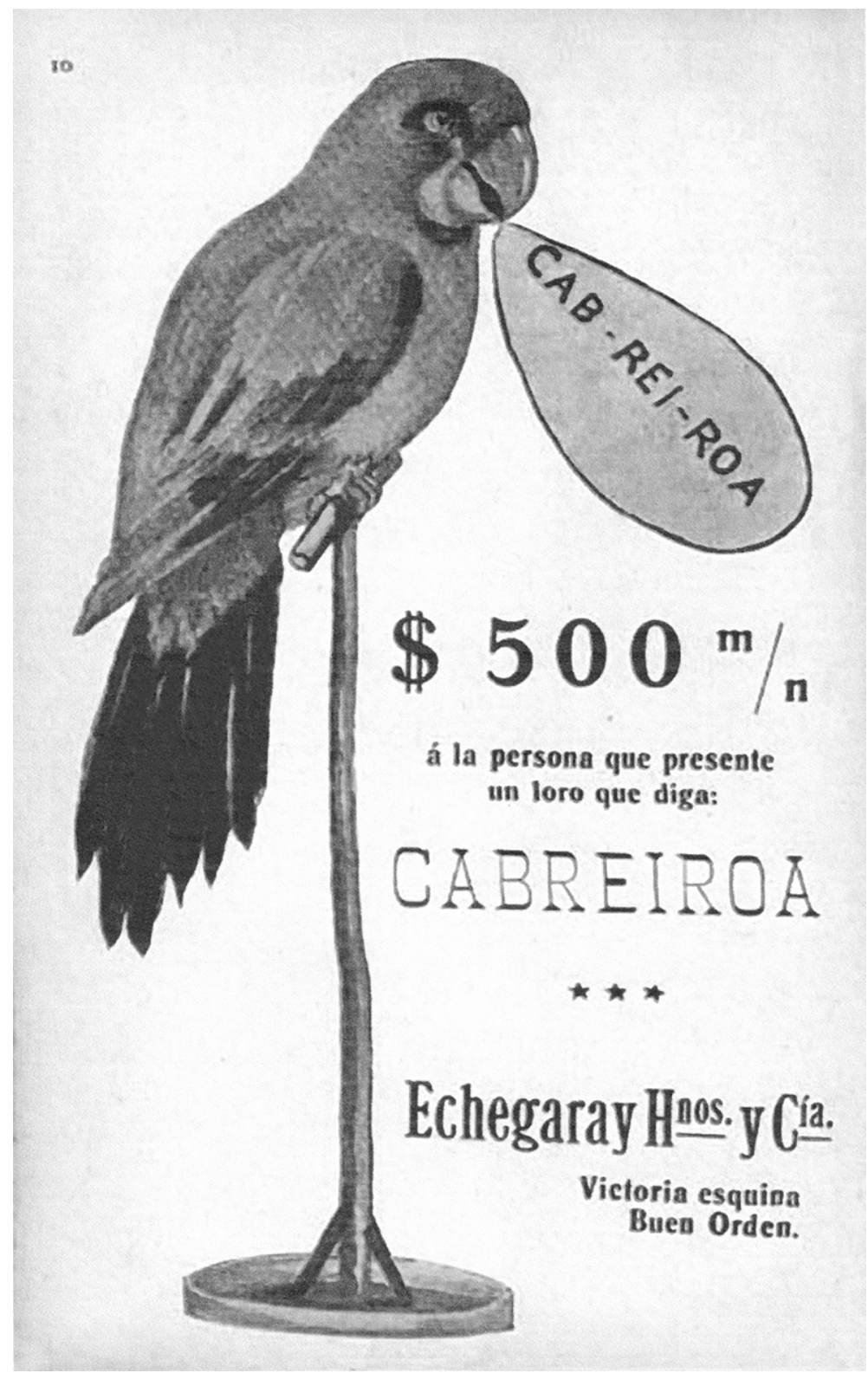

Figura 12 - Anúncio da firma portenha "Echegaray Hermanos y Cia" publicada no número 153 da revista argentina PTB, 19 de outubro de 1907. 
períodos menores, cobrando-se uma pequena taxa adicional pela aprendizagem de frases pouco usuais ou sentenças em outro idioma. Muitos anos depois, em setembro de 1931, a revista "Modern Mechanics and Inventions" traria a notícia de que Peter Jansen, veterano treinador de aves do "Luna Park" de Los Angeles, teria passado a utilizar esse método e formaria "turmas" de quatro ou cinco "alunos", empregando gravações destinadas a esse fim contendo frases como "louro bonito", "olá louro" etc. Com uma hora de duração, as aulas pareciam despertar notável interesse em seus pupilos, pois mesmo aqueles menos capacitados teriam começado a falar após seis dias (Figura 14). Ainda mais desusada - e bem mais recente - seria a tentativa levada a cabo por outro americano, um ornitólogo chamado Ray Berunck, de criar um centro destinado à formação de "papagaios-guia" para cegos. Nesse local, as aves aprenderiam palavras-chave como "pare", "vire à esquerda", além de passar a atender sinais luminosos, distinguir obstáculos etc. Entre as vantagens apontadas, destacava-se o fato de os papagaios necessitarem de manutenção mais barata e terem uma vida muito mais longa que os cães, sendo cotados entre 250 e 400 dólares. ${ }^{94}$

No Brasil, a cultura popular não para de engendrar novas "piadas de papagaio" - termo assaz sugestivo - e continua registrando um número considerável de eventos reais capazes de enriquecer o rico folclore relativo a essas aves. Entre os casos dignos de despertar o interesse da população e ganhar as páginas dos jornais, alinham-se desde um roubo evitado por um papagaio que chamou a polícia em altos brados, até outro exemplar preso em uma rede e salvo graças a seus insistentes apelos por socorro. ${ }^{95}$ Tampouco faltam exemplos de aves processadas por sua extrema maledicência, algo assinalado desde o começo do século XVII pelo "inca" Garcilazo de la Vega. Em Sevilha, de acordo com esse cronista, um papagaio acostumado a afrontar certo "médico indigno" com uma torrente de ofensas seria alvo de uma queixa à justiça, a qual decidiu que o dono desse boquirroto volátil deveria mantê-lo longe da rua sob pena de ter de entregá-lo ao reclamante. ${ }^{96} \mathrm{Na}$ Paris de 1792, durante o auge do Terror, outro exemplar terminaria sendo acusado de atividades contrarrevolucionárias, pois gritava a plenos pulmões "Viva o Rei!", "Viva os nossos sacerdotes!", "Viva os nobres!". O papagaio e suas proprietárias, madame Louise de la Fiefville e "mademoiselle" Françoise de Béthune, foram presos e levados diante do tribunal. Como a ave recusou-se a falar em juízo, os réus terminariam sendo libertados pela falta de evidências, mas obrigou-se o papagaio reacionário a ser politicamente doutrinado por uma "tricoteuse" - a cidadã Le Bon - aprendendo a repetir "Viva a Nação!" e um vasto repertório de pragas e canções obscenas antes de voltar para sua antiga residência. ${ }^{97}$ No Rio de Janeiro, em 2004, seria a vez da dona de um papagaio ser autuada por danos morais pelo fato de seu bicho de estimação pôr sistematicamente em dúvida a honestidade de todas as mulheres - e a masculinidade de todos os homens - que the caíam sob os olhos. ${ }^{98}$
The Parrot, Je garde les Poulets, [I look after the Chickens]. The Prince laugh'd, and said, Vous gardez, les Poulets? [You look after the Chickens?] The Parrot answer'd, Ouy moy, E je le say bien faire, [Y's I, and I know bow to do it well]; and made the Chuck Four or Five Times that People use to make to Chickens when they call them. I set down the Words of this worthy Dialogue in French, just as Prince Maurice said them, to me. I ask'd him, In what Language the Parrot spoke? and he said, In Brasilian. I ask'd, Whether he understood Brasilian? he said, No; but he had taken Care to have Two Interpreters by him, one a Dutchman that spoke Brasilian, and t'other a Brasilian that spoke Dutch: That he ask'd them separately and privately, and both of them agreed in telling him just the same thing that the Parrot said. I cou'd not but tell this odd Story, because it is so much out of the Way, and from the first Hand, which may well pass for a good one; for I dare say this Prince, at least believ'd himself, in all he told me, having ever pass'd for a very honest and pious Man. I leave it to $\mathrm{Na}$ turalists to reason, and to other Men to believe as they please upon it; however, it is not perhaps amiss to relieve or enliven a busy Scence sometimes with such Digressions, whether to the Purpose or not" no original (Temple, 1689).

75. Trata-se de dois volumes já encadernados de aquarelas e desenhos também conhecidos como "Manuais" graças à presença de notas do punho de Johan Maurits van Nassau-Siegen. Embora certos autores estimem 1660 como data aproximada de sua elaboração, certos detalhes das ilustrações e o próprio conteúdo dos textos comprovam que esta iconografia foi elaborada no Brasil, portanto entre 
1633 e 1644 . Na verdade, os "Libri Principis" parecem ter sido desenvolvidos como uma espécie de cartilha ou "manual" destinados à educação e o recreio de Johan Maurits van Nassau-Siegen, que assim poderia melhor conhecer os animais e plantas de seus vastos domínios no Novo Mundo. Uma vez que cada potentado da época almejava ser considerado um filósofo, torna-se difícil resistir à ideia de que Nassau se comprazia em registrar observações pessoais sobre exemplares de seu plantel nesses livros previamente estruturados pelos pintores e naturalistas da corte, encarregados de ilustrar os volumes e obter elementos indicativos, como o nome popular de cada espécie a ser apreciada pelo Príncipe durante seus passeios. Para maiores detalhes, vide Teixeira $(1995,1999)$.

76. Blokland; Oliveira (2007). Variações dessa mesma história também existem no folclore europeu envolvendo diferentes personagens.

\section{Daniel (1975)}

78. Em 1832, durante suas viagens na Bacia do Prata, o naturalista inglês registraria serem as caturritas tão destrutivas para os milharais que se pagava certa quantia por cada dúzia de cabeças apresentadas, havendo registro de 2.500 espécimens abatidos apenas na Colônia de Sacramento em um único ano ("they are very destructive to the corn-fields. I was assured that in one year, near Colonia del Sacramiento, on the north bank of the La Plata, 2,500 were killed, a reward being given for each dozen heads" no original; Darwin, 1841, 1860). Consta ainda ter o general Justo José de Urquiza, governador de Entre Rios entre 1842 e 1853 , adotado a medida extrema de estabelecer um dízimo de psitácidas a serem mor-

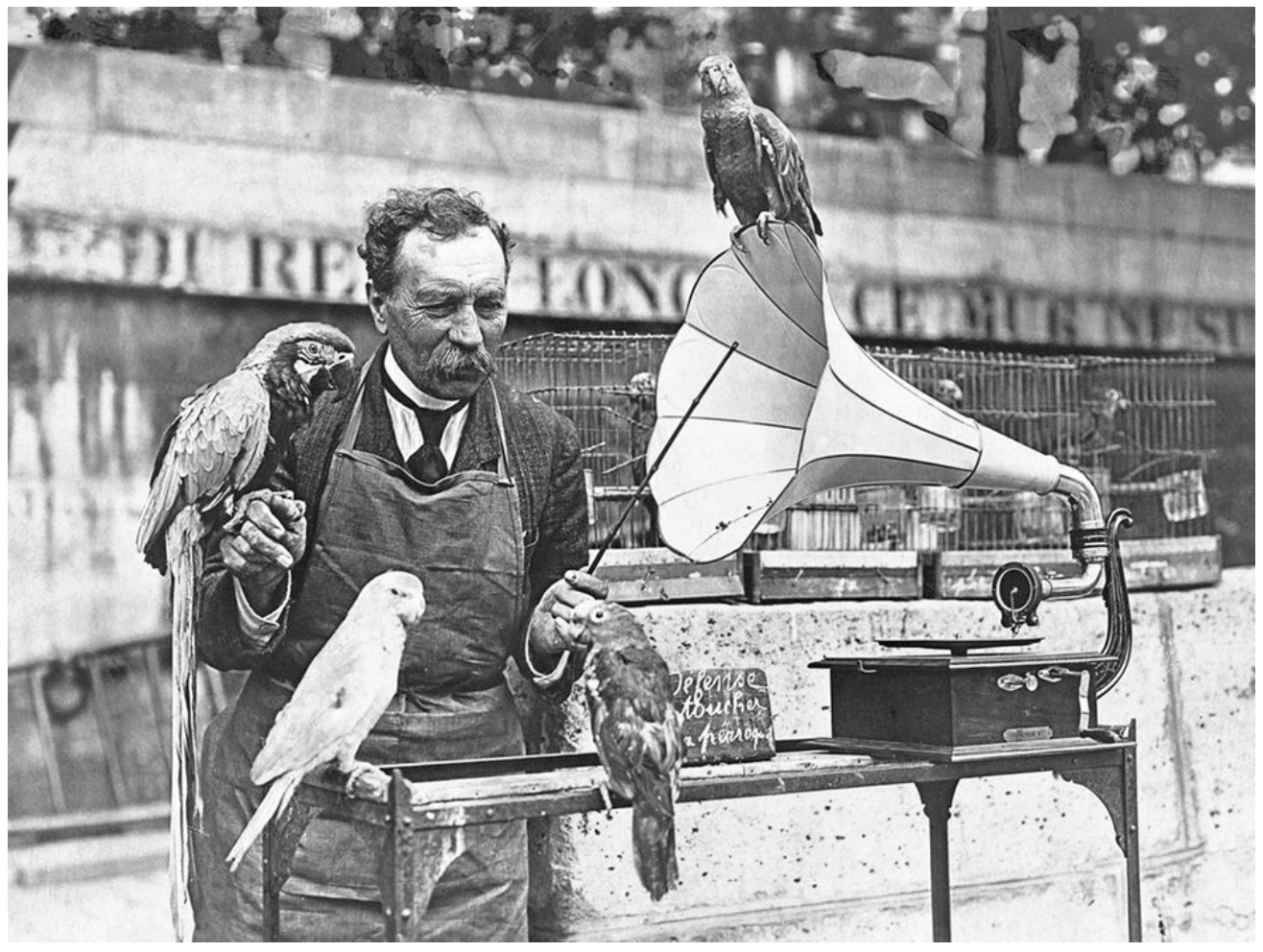

Figura 13 - Psitácidas sendo adestrados com o auxílio de um fonógrafo, ca. 1935. Coleção privada, Alemanha.

Para concluir, seria pertinente mencionar duas surpreendentes notícias envolvendo aves falantes, no caso um mainá, Acridotheres tristis (Linnaeus, 1766) - espécie bastante conhecida por sua capacidade de imitar a voz humana - e um papagaio-do-congo, Psittacus erithacus (Figuras 1 e 15). Segundo matéria divulgada pela BBC em 20 de junho de 2001 ,

uma dona de casa chinesa descobriu que seu marido a traía depois de receber indicações do pássaro do casal, um mainá. Ela percebeu que o vocabulário do pássaro tinha mudado quando voltou para casa após uma visita de um mês a seus pais. Em vez das palavras de sempre, o mainá repetia expressões como "eu te amo", "tenha paciência" e "divórcio". O pássaro ficava mais comunicativo quando o telefone tocava, aumentando as suspeitas da mulher de que o mainá ouvia as conversas do marido infiel com sua amante. Certa da traição do marido, a dona de casa da cidade de Chung Ching, sudoeste da China, entrou com um pedido de divórcio. Ela espera que o juiz aceite o "testemunho" do mainá sobre a infidelidade do marido. Os advogados da dona de casa, no entanto, não acreditam que um juiz garanta o divórcio com base nas palavras do mainá. ${ }^{99}$

Contudo, outra reportagem, veiculada pela mesma BBC em 27 de junho de 2016 , mostrar-se-ia ainda mais inusitada ao destacar que "Bud", um papagaiodo-congo, vem sendo encarado como a testemunha-chave do assassinato de Martim Duram por sua esposa Glena, crime cometido no ano de 2015. Segundo 
consta, essa ave teria registrado as últimas palavras do morto ao repetir claramente certo diálogo travado entre um homem e uma mulher que terminava com a frase "não atire!" seguida por uma expressão obscena. Apesar de tudo, Robert Springstead - promotor do condado de Newaygo, Michigan - acha improvável que "Bud" seja chamado a depor durante o julgamento. ${ }^{100}$

A possibilidade de lançar mão de testemunhos tão incomuns transcende a mera curiosidade e não só ressalta a forte tendência de humanizar os animais observada nos dias de hoje, como exemplifica o quão multifacetadas podem ser as relações do homem com o chamado "mundo natural", revelando um universo além de qualquer previsão em termos de sua amplitude e complexidade. Nesse sentido, a existência de aves com o dom da palavra - papagaios ou mainás torna essa convivência ainda mais intrincada e evidencia que as centenárias dificuldades de estabelecer limites entre o animal e o humano continuam bastante presentes e se estendem muito além dos primatas, envolvendo as mais inesperadas espécies zoológicas. ${ }^{101}$

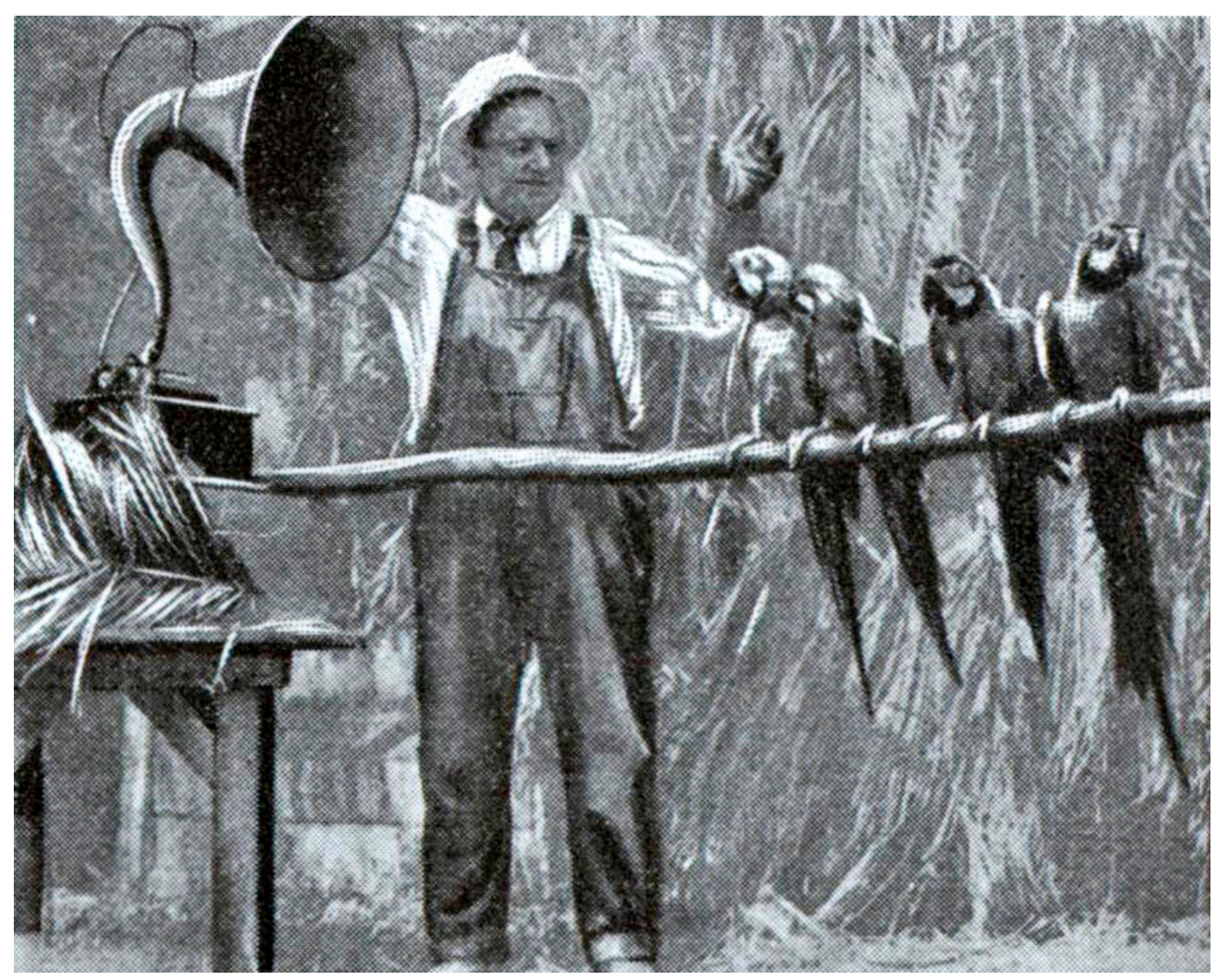

Figura 14 - Araras sendo adestradas com o auxílio de um fonógrafo por Peter Jansen, treinador de aves do "Luna Park" de Los Angeles. Foto da "Modern Mechanics and Inventions", setembro de 1931. tos anualmente por cada homem adulto da província. Como os habitantes citadinos encontravam grande dificuldade em atender semelhante determinação, logo surgiram caçadores profissionais dispostos a suprir a demanda. Vide Santos (1952).

79. Audubon (1831).

80. Hume; Walters (2012) e Snyder (2004).

81. Ou seja, Amazona aestiva, Pyrrbura frontalis (Vieillot, 1817), Pyrrbura leucotis (Kuhl, 1820), Forpus xanthopterygius (Spix, 1824), Aratinga aurea, Ara severa (Linnaeus, 1758), Primolius maracana, Brotogeris tirica (Gmelin, 1788) e Myiopsitta monachus. Além de espantalhos, tiros de espingarda, venenos e até mesmo fogos de artifício, os agricultores usariam o expediente de dobrar os pés de milho por acreditarem que os psitácidas não conseguiriam alcançar as espigas pendentes, Anônimo (1919), Berlepsch; Ihering (1895), Goeldi (1894), Santos (1952).

82. "Em relação a passaros, observou-se bem curioso facto na Laguna, sul de Santa Catarina. Outr'ora, aquella cidade sustentava animado commercio por meio da salga dos bagres, que pullulavam nas bacias internas, formadas pelo mar e pelas aguas do rio Tubarão na sua foz. De uns dez ou quinze annos para cá, escasseou, porém, e de modo pasmoso essa proveitosa fonte de receita, porque uma ave aquatica, o biguá, depois de muitas e infructiferas tentativas, aprendeu a quebrar os ferrões daquelle peixe para poder engolil-o, o que antes não sabia fazer. E a quantidade dos biguás que para lá affluio, pondo em pratica a descoberta, foi tal, que a pescaria do homem se tornou muito pouco rendosa. 
Tambem a camara municipal instituio premios em dinheiro para quem apresentasse certo número de biguás mortos. E, com effeito, encetada a destruição dos incansaveis e innumeros perseguidores, vai o peixe reaparecendo e contentando mais os pescadores da Laguna, ainda que taes passaros não se mostrem dispostos a facilmente abandonar o terreno da concurencia e da luta" no original, Taunay (1921)

83. Sobre essa discussão, vide Bucher (1992), Collar (1997) e Sick (1985) versus González (2001) e Ojasti (1993).

84. Elenco formado por Ara severa, Primolius maracana, Cyanoliseus patagonus, Aratinga leucophthalma (Statius Muller, 1776), Aratinga weddellii (Deville, 1851), Aratinga canicularis (Linnaeus, 1758), Aratinga pertinax (Linnaeus, 1758), Forpus passerinus (Linnaeus, 1758), Pionus maximiliani (Kuhl, 1820), Pionus senilis (Spix, 1824), diferentes psitácidas do gênero Amazona e a inevitável caturrita, Myopsitta monachus. Vide Bodrati et al. (2006), Bucher (1984), Dabenne (1935), Elias; Valencia (1984), Forshaw (1978), González (2001), Grazio (1978) e Ojasti (1993).

85. Berlepsch; Ihering (1895), Bertels (1979) e Ihering (1899). Segundo informação prestada pelo Dr. Luis Flamarion Barbosa de Oliveira, Departamento de Vertebrados, Museu Nacional - UFRJ, duas testemunhas independentes - uma dos quais sua própria genitora - relataram ter avistado um gigantesco grupo de charões que sobrevoou a cidade de Vacaria durante o inverno de 1950. Avaliado em cerca de um quilômetro de largura, esse bando teria demorado em torno de 45 minutos para passar sobre a cabeça de ambos os ob-

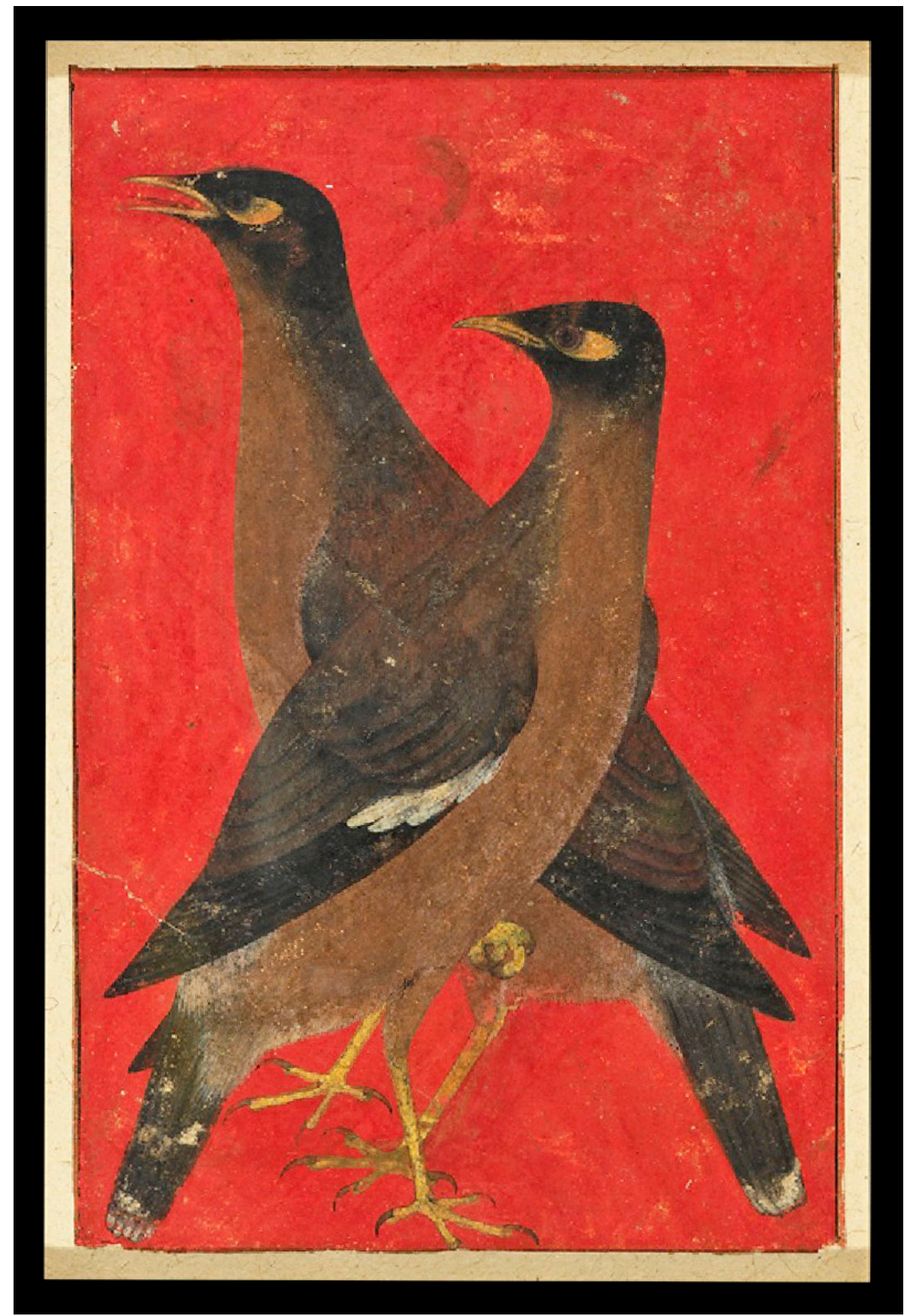

Figura 15 - Mainá, Acridotheres tristis, segundo ilustração do Período Mughal, ca. 1620. Ashmolean Museum, Oxford. 
servadores. Vide também Fontana et al. (2003).

86. González (2001).

87. Bernardon; Valsecchi (2013).

\section{FONTES IMPRESSAS}

ALDROVANDI, Ulisse. Ornithologiae hoc est de avibus historia libri XII. Bononiae: Franciscis Senensem, 1599-1603.

ANCHIETA, Joseph de. Epistola quam plurimarum rerum naturalium quae S. Vicenti (nunc St. Pauli) provinciam incolunt, sistens descriptionem. Noticias para a Historia e Geografia das Nações Ultramarinas. Lisboa, v. 1, n. 1-3, p. 127-178, 1812.

APULEIO. The works of Apuleius. London: Bell \& Daldy, 1866.

ARISTÓTELES. History of Animals. Cambridge, Massachusetts: Harvard University Press, 1965-1991.

ARRIANO. Anabasis Alexandri, Indica. Cambridge, Massachusetts: Harvard University Press, 1976.

AUDUBON, John James. Ornithological biography, or an account of the habits of the birds of the United States of America. Edinburgh: Adam Black, 1831.

BASSUS, Cassianus. Geoponicorvm sive De Re Rvstica Libri XX. Lipsia: Caspari Fritsch, 1781.

BIBAR, Gerónimo de. Cronica y relación copiosa y uerdadera de los reynos de Chile. Santiago de Chile: Fondo Histórico y Bibliográfico José Toribio Medina, 1966.

BOGUET, Henry. Discours des Sorciers. Lyon: Rigaud, 1590.

BRANDÃO, Ambrósio Fernandes. Dialogos das grandezas do Brasil. Rio de Janeiro: Academia Brasileira de Letras, 1930.

CARDIM, Fernão. Tratados da Terra e da Gente do Brasil. São Paulo, Companhia Editora Nacional, 1939.

CESARIUS de HEISTERBACH. Dialogus Miraculorum. Coloniae: J.M. Heberle, 1851.

CÉSPEDES, Diego de. Libro de conjuros contra tempestades, contra oruga, y arañuela, contra duendes, y bruxas, contra peste, y males contagiosos, contra rabia, y contra endemoniados, etc. Sacados de missales, manuales, y breviarios romanos, y de la Sagrada Escritura. Pamplona: Heredera de Carlos de Labayen, 1641.

CIEZA DE LEÓN, Pedro. Parte primera de la chronica del Peru. Seuilla: Martin de Montesdoca, 1553.

CONCEPCION, Luis de la. Pratica de conjurar. Alcalá: Imp. Francisco García Fernández, 1673.
88. Os problemas criados por Myiopsitta monachus têm sido muito discutidos por autores como Bucher (1984, 1992) e Davis (1971). No ano de 1964, essa espécie seria declarada oficialmente uma praga agrícola na Argentina, integrando uma lista da qual também fazem parte quatro outros psitácidas, a saber: Cyanoliseus patagonus, Aratinga acuticaudata (Vieillot, 1818), Amazona aestiva e Pionus maximiliani. Vide Canavelli et al. (2012)

89. Bucher; Martín (1987), Ana Laura Campos de Carvalho (2015), Cavitione e Silva (2014), Höfling; Camargo (1993), Marchini; Ferraz (2014) e Sacco et al. (2013).

90. Vide, por exemplo, as pretensas ocorrências envolvendo um papagaio-do-congo Psittacus erythacus (disponível em <http:// www.spiritualresearchfoun dation.org/spiritualresear $\mathrm{ch} /$ spiritualscience/talking parrot>, consultado em agosto de 2016) e um tiriba, Pyrrbura molinae (Massena \& Souancé, 1854) (disponível em <http://www. parrotforums.com/ conures/36005-temporarydemon-possession-green cheek-conure.html>, con-

91. Grindol; Roudybush (2004), Jiménez (2011) e Knight (1961). Em 1558, Gerónimo de Bibar presenciaria inusitada prática dos comechingones de envolver os papagaios em um tecido, amarrá-los e pô-los em uma panela ao fogo para que começassem a falar ("Hay muchos papagayos y las plumas son preciadas entre ellos, y avénzanlos a hablar sultado em 15 set. 2016) 
de una manera que nunca tal he oído, que es envolverlos en una mantilla y los atan y ponen en una cazuela a1 fuego. Métenle dentro y con la calor da el papagayo muy grandes graznidos de como se tuesta. Tienen ellos que de aqui les queda el hablar" no original; Bilbar, 1966). Já os "nossos caipiras tiram os filhotes dos ninhos e os acabam de criar a mão. Quando o filhote já está bem empenado, dão-lhe um banho tremendo de água fria, colocam-no em uma cabaça de gargalo e pela abertura na extremidade vão proferindo as palavras ou as frases desejadas [...] Repetindo duas vezes por dia essa operação, no fim de uma semana o papagaio já fala mais ou menos, sendo-lhe daí em diante dadas lições em liberdade, quase sempre por mulheres" (Anônimo, 1913).

92. "A widow gentlewoman, well born both by father and mother' side, being the daughter of Thomas Prater, once an eminent practitioner in the law, and of Letitia Tattle, a family well known in all parts of this kingdom, having been reduced by misfortunes to wait on several great persons, and for some time to be a teacher at a boarding-school of young ladies, giveth notice to the public, That she hath lately taken a house near Bloomsbury-square, commodiously situated next the fields in a good air; where she teaches all sorts of birds of the loquacious kinds, as parrots, starlings, magpies, and others, to imitate human voices in greater, perfection than ever was yet practised. They are not only instructed to pronounce words distinctly, and in a proper tone and accent, but to speak the language with great purity and volubility of tongue, together with all the fashionable phrases and compliments now in use
CRISTÓVÃO DE LISBOA. História dos Animais e Árvores do Maranhão. Lisboa: Arquivo Histórico Ultramarino \& Centro de Estudos Históricos Ultramarinos, 1967.

História dos Animais e Árvores do Maranhão. Lisboa: Comissão Nacional para as Comemorações dos Descobrimentos Portugueses \& Instituto de Investigação Científica Tropical, 2000.

DANIEL, João. Tesouro descoberto no Rio Amazonas. Anais da Biblioteca Nacional. Rio de Janeiro, v. 95, n. 1, p. 1-437, 1975.

DARWIN, Charles. (ed.). The Zoology of the voyage of H.M.S. Beagle, under the command of captain Fitzroy, R.N., during the years 1832 to 1836. London: Smith, Elder and Co., 1841. Part III: Birds.

Journal of Researches into the Natural History and Geology of the countries visited during the voyage of H.M.S. Beagle round the worl, under the command of Capt. Fitz Roy, R.N. London: John Murray, 1860.

FERREIRA, Diogo Fernandes. Da caça da alteneria. Lisboa: Officina de Iorge Rodriguez, 1616.

GASCON, Antonio. Fasciculus exorcismorum, conjuratonium, orationum ac benedictionum contra procellas, ventos, locustas, aliosque vermes et animalia fructuum corrosiva. Zaragoza: Herederos de Martínez, 1627.

GESNER, Conrad. Historiae Animalium Liber III. qui est de Auium natura. Tigvri: Christoph. Froschovervm, 1555.

GÓIS, Damião de. Chronica do felicissimo rei dom Emanvel, composta por Damiam de Goes, dividida em quatro partes. Lisboa: Francisco Correa, 1566.

GUAZZO, Francesco Maria. Compendivm Maleficarvm. Mediolani: Haeredes August. Tradati, 1608 .

GUSMÃO, Alexandre de. A arte de crear bem os filhos na idade da puericia. Lisboa: Officina de Miguel Deslandes, 1685.

HOPKINS, Matthew. The Discovery of Witches. London: R. Royston, 1647.

HUGHES DE SAINT-VICTOR. M. Hvgonis de S. Victore, canonici regvlaris Sancti Victoris parisiensis, tvm pietate, tvm doctrina insignis; Opera Omnia tribvs tomis digesta. Rothomagi: Sumptinus Ioannia Berthelin Bibliopolae, 1648. Tomus secundus.

HUMBOLDT, Alexander von. Ansichten der Natur. Tübingen: J.G. Cotta'schen Buchhandlung, 1808.

; BONPLAND, Aimé. Personal narrative of travels to the Equinoctial Regions of the New Continent during the years 1799-1804. London: Longman, Hurst, Rees, Orme and Brown, 1814.

KRAMER, Heinrich; SPRENGER, James. Malleus maleficarum, Argentorati: J. Prüss, 1490. 
JUAN DE SANTA GERTRUDIS. Maravillas de la naturaleza. Bogotá: Comissión Preparatoria para el V Centenario del Descubrimiento de América \& Instituto Colombiano de Cultura, 1994.

LAS CASAS, Bartolomeu de. Historia de las Indias. Madrid: Imprenta de Miguel Ginesta, 1875.

LERY, Jean de. Histoire d'un voyage fait en la terre du Bresil, avtrement dite Amerique. La Rochelle: Antoine Chuppin, 1578.

LOCKE, John. An Essay concerning Humane Understanding. London: Tho[mas] Basset, 1690.

LÓPEZ DE GÓMARA, Francisco. Primera y Segunda parte de la Historia General de las Indias con todo el descubrimiento y cosas notables que han acaecido dende que ganaron ata el año de 1551. Çaragoça: Augustin Millan, 1552.

LOZANO, Pedro. Historia de la conquista de las provincias del Paraguay, Río de la Plata y Tucumán. Buenos Aires: Academia Nacional de la Historia, 2010.

LUTERO, Martinho. Martin Luthers Werke: Tischreden. Weimar: Hermann Böhlaus Nachfolger, 1912-1921.

MATHER, Increase. An Essay for the Recording of Illustrious Providences: wherein, An Account is given of many Remarkable and very Memorable Events, which have happened in this last Age; especially in New-England. Boston: Samuel Green, 1684.

MELÉNDEZ, Juan. Tesoros verdaderos de las Yndias en la Historia de la gran Prouincia de San Ivan Bavtista del Perv. Roma: Imprenta de Nicolas Angel Tinassio, 1681.

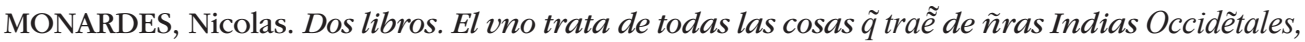
que siruen al vso de Medicina, y como se ha de vsar dela rayz del Mechoacã, purga excelétissima. El otro libro, trata de dos medicinas marauillosas q̃ son cõtra todo Veneno, la piedra Bezaar, y la yerua Escuerçonera. Con la cura de los Venenados. Do veran muchos secretos de naturaleza y de medicina, cõ grãdes experiẽcias. Sevilla: Casa de Sebastian Trugillo, 1565.

[MONTALBODDO, Fracanzano da]. Paesi nouamente retrouati. Et Nouo Mondo da Alberico Vespucio Florentino intitulato. Vicentia: Henrico Vicentino, 1507.

OVIEDO Y VALDÉS, Gonzalo Fernández. De la Natural Hystoria de las Indias. Toledo: Remón de Petras, 1526.

PAUCKE, Florián. Hacia allá y para acá (una estada entre los indios Mocobies, 1749-1767). Tucuman: Universidad Nacional de Tucuman, 1942-1944.

PHOTIUS. The Library of Photius. New York: Macmillan, 1920. Photius Bibliothèque. Paris: Les Belles Lettres, 1959.

PLÍNIO, O VELHO. Pliny Natural History. Cambridge, Massachusetts: Harvard University Press \& William Heinemann, 1979-1984. either at tea-tables, or visiting-days. Those that have good voices may be taught to sing the newest opera-airs, and, if required, to speak either Italian or French, paying something extraordinary above the common rates. They whose friends are not able to pay the full prices, may be taken as half boarders. She teaches such as are designed for the diversion of the public, and to act in enchanted woods on the theatres, by the great. As she has often observed with much concern how indecent an education is usually given these innocent creatures, which in some measure is owing to their being placed in rooms next the street, where, to the great offence of chaste and tender ears, they learn ribaldry, obscene songs, and immodest expressions from passengers, and idle people, as also to cry fish and card-matches, with other useless parts of learning to birds who have rich friends, she has fitted up proper and neat apartments for them in the back part of her said house; where she suffers none to approach them but herself, and a servant maid who is deaf and dumb, and whom she provided on purpose to prepare their food, and cleanse their cages; having found by long experience how hard a thing it is for those to keep silence who have the use of speech, and the dangers her scholars are exposed to, by the strong impressions that are made by harsh sounds, and vulgar dialects. In short, if they are birds of any parts or capacity, she will undertake to render them so accomplished in the compass of a twelvemonth, that they shall be fit conversation for such ladies as love to choose their friends and companions, out of this species" no original (Steele, 1816).

93. Anônimo (1913). 
94. Morozov (1983).

95. Segundo reportagens publicadas em "O Globo" de 23 de setembro de 2003 e 12 de março de 2004.

96. "En Seuilla en Caldefrancos pocos años ha auia otro Papagayo, que en viendo passar vn cierto medico, indigno del nombre, le dizia tantas palabras afrentosas que le forçõ a dar quexa del. La justicia mando a su dueño que no lo tuuiesse en la calle, sopena que se lo entregarian al ofendido" no original (Vega, 1609).

97. Bondeson (1999).

98. Segundo reportagem publicada em "O Globo" de 30 de agosto de 2004 .

99. Disponível em <http:// news.bbc.co.uk/2/hi/asiapacific/1398195.stm>, consultada em 15 set. 2016.

100. Disponível em <http:// www.bbc.com/news/worldus-canada-36643494>, consultada em 15 set. 2016.

101. Agradecemos a Nelson Papavero (Museu de Zoologia, USP) pelas sugestões apresentadas ao manuscrito, a Luis Flamarion Barbosa de Oliveira (Departamento de Vertebrados, Museu Nacional - UFRJ), pelas informações sobre Amazona pretrei no Rio Grande do Sul e a Paula de Vries Albertin pela fotografia de "Os Efeitos da Intemperança” de Jan Steen (1663-1665).
PRIERATIS, Silvestri. De strigimagarum, daemonumque mirandis, libri tres. Roma: Aedibus Populi Romani, 1575.

REMIGIO, Bento. Pratica de exorcistas y ministros de la iglesia. Barcelona: Antonio la Cavalleria, 1688.

ROSALES, Diego de. Historia general de el Reyno do Chile. Valparaiso: Imprenta del Mercurio, 1877.

SANCHEZ LABRADOR, Joseph. Peces y aves del Paraguay Natural ilustrado, 1767. Buenos Aires: Compañia General Fabril Editora, 1968.

SOUSA, Gabriel Soares de. Tratado descriptivo do Brasil em 1587. São Paulo: Companhia Editora Nacional, 1938.

SOUSA, Pero Lopes de. Diario da navegação de Pero Lopes de Sousa 1530-1532. Rio de Janeiro: Typographia Leuzinger, 1927.

TEMPLE, William. Memoirs of what pass'd in Christendom from the war begun in 1672, to the Peace concluded 1679. London: Richard Chiswell, 1689.

VALDECEBRO, André Ferrer de. Govierno general, moral, y politico hallado en las aves mas generosas, y nobles, sacado de svs natvrales, virtvdes, y propriedades. Madrid: Melchor Alegre, 1670.

TAUNAY, Alfredo d'Escragnolle, 1921. Viagens de outr'ora. São Paulo: Editora Melhoramentos, 1921.

VASCONCELlOS, Simão de. Chronica da Companhia de Jesv do Estado do Brasil. Lisboa: Officina de Henrique Valente de Oliueira, 1663.

Vida do veneravel Padre Ioseph de Anchieta da Companhia de Iesv, tavmatvrgo do Nouo Mundo, na Prouincia do Brasil. Lisboa: Officina de Ioam da Costa, 1672.

VEGA, Garcilaso de la. Commentarios Reales, que tratam del origen de los Yncas, reyes que fveron del Perv, de sv idolatria, leyes, y gouierno en paz y em guerra: de sus vidas y conquistas, $y$ de todo lo que fue aquel Imperio y su Republica, antes que los Españoles passaran a el. Lisboa: Officina de Pedro Crasbeeck, 1609.

WILLUGHBY, Francis. Ornithologiae libri tres: In quibus Aves omnes hactenus cognitae in methodus naturis suis convenientem redactae accuratè describuntur. Londini: Impensis Joannis Martyn, 1676.

YVES D'EVREUX. Svitte de L'Histoire des choses plus memorables aduenuës en Maragnan, es années 1613 \& 1614. Paris: François Huby, 1615. 
ABLEY, Mark. Spoken here: travels among threatened languages. Toronto: Random House, 2003.

AMAT, Jacqueline. Les animaux familiers dans la Rome antique. Paris: Les Belles Lettres, 2002.

ANÔNIMO. Our pets, sketches of the furred and feathered favourites of the young. London: Groombridge \& Sons, [ca. 1870].

53-58, 1913

Como se ensina os papagaios a falar. Chacaras e Quintaes, São Paulo, v. 8, n. 5, p.

. As "catorritas" (periquitos do milharal) e como destruí-las. Chacaras e Quintaes, São Paulo, v. 20, n. 1, p. 54-55, 1919.

ARNOTT, William Geoffrey. Birds in the Ancient World from A to Z. London: Routledge, 2007.

BECHTEL, Guy. La sorcière et l'Occident. Paris: Plon, 1997.

BECKERS, Gabriel J.L.; NELSON, Brian S.; SUTHERS, Roderick A. Vocal-tract filtering by lingual articulation in a parrot. Current Biology. Cambridge, v. 2004, n. 14, p. 1592-1597, 2004.

BEDINI, Silvio Anthony. The Pope's Elephant. Nashville: J.S. Sanders, 1998.

BERGIER, Nicolas-Sylvestre. L'origine des dieux du paganisme. Paris: Humelot, 1774.

BERLEPSCH, Hans von; IHERING, Hermann von. Die Vögel der Umgegend von Taquara do Mundo Novo, Prov. Rio Grande do Sul. Zeitschrift die gesammte Ornithologie. Budapest, v. 1885, p. 97-185, 1895.

BERNARDON, Bianca; VALSECCHI, João. Aves em plantios na Reserva de Desenvolvimento Sustentável Amanã, Amazonas, Brasil. In: SIMPÓSIO SOBRE CONSERVAÇÃO E MANEJO PARTICIPATIVO NA AMAZÔNIA, 10, 2013, Tefé. Resumos ... Tefé: Instituto de Desenvolvimento Sustentável Mamirauá \& CNPq, 2013. p. 27.

BERTELS, Andrej. Aves prejudiciais para agricultura no Rio Grande do Sul. Agros, Pelotas, v. 14, n. 1, p. 41-46, 1979.

BEUSTERIEN, John. Canines in Cervantes and Velázquez: an animal studies regarding of early modern Spain. Aldershot: Ashgate, 2013.

BLOKLAND, Ann; OLIVEIRA, Judith de Jong Andrade. O holandês imaginário: lendas do Brasil holandês. Recife: Editora do Autor, 2007.

BODRATI, Alejandro; COCKLE, Kristina; ARETA, Juan Ignacio; CAPUZZI, Gabriel; FARIÑA, Rodrigo. El maracaná lomo rojo (Primolius maracana) en Argentina: ¿de plaga a la extinción en 50 años? Hornero. Buenos Aires, v. 21, n. 1, p. 37-43, 2006. 
BOEHRER, Bruce Thomas. Parrot Culture, our 2,500-year-long fascination with the world's most talkative bird. Philadelphia: University of Pennsylvania Press, 2004.

. Animal characters: nonhuman beings in early modern literature. Philadelphia: University of Pennsylvania Press, 2010.

BONDESON, Jan. The Feejee mermaid and other essays in Natural and Unnatural History. Ithaca: Cornell University Press, 1999.

BOUGEANT, Guillaume Hyacinthe. Amusement philosophique sur le langage des bêtes. La Haye: Antoine van Dole, 1753.

BUCHER, Enrique Hugo. Las aves como plagas en la Argentina. Córdoba: Universidad Nacional de Córdoba, 1984

Neotropical parrots as agricultural pests. In: BEISSINGER, Steven; SNYDER, Noel (ed.). New World parrots in crisis: solutions from conservation biology. Washington DC: Smithsonian Institution Press, 1992. p. 73-115.

; MARTÍN, Liliana Fernández. Los nidos de cotorras (Myiopsitta monachus) como causa de problemas en líneas de transmisión eléctrica. Vida Silvestre Neotropical. São José da Costa Rica, v. 1, n. 2, p. 50-51, 1987.

BUFFON, George-Louis Leclerc, Comte de. Histoire Naturelle, Générale et Particulière, avec la description du Cabinet du Roi. Paris: Imprimerie Royale, 1780 (vol. 11: Histoire Naturelle des Oiseaux).

CANAVELlI, Sonia Beatriz; ARAMBURÚ, Rosana; ZACCAGNINI, Maria Elena. Aspectos a considerar para disminuir los conflictos originados por los daños de la cotorra (Myiopsitta monachus) en cultivos agrícolas. Hornero. Buenos Aires, v. 27, n. 1, p. 89-101, 2012.

CARVAlHO, Ana Laura Campos de. Psittacara leucophthalmus (Aves: Psittacidae) e seus impactos sobre a agricultura na mesorregião Campo das Vertentes, Minas Gerais: ecologia e etnobiologia como subsídios ao manejo. Viçosa: Dissertação (Mestrado) - Pós-Graduação em Biologia Animal. Universidade de Viçosa, 2015.

CARVAlHO, Francismar Alex Lopes de. Imagens do demônio nas missões jesuíticas da Amazônia espanhola. Varia Historia. Belo Horizonte, v. 31, n. 57, p. 741-785, 2015.

CARVAlHO, João de Paiva. Papagaios, maitacas e periquitos. Chacaras e Quintais. São Paulo, v. 66, n. 5 , p. $612-613,1942$.

CARVALHO, Manuel Emílio Gomes de. D. João III e os francezes. Lisboa: Livraria Classica Editora, 1909.

CASCUDO, Luís da Câmara. Dicionário do Folclore Brasileiro. Rio de Janeiro: Instituto Nacional do Livro, 1954.

Tradições populares da pecuária nordestina. Rio de Janeiro: Ministério da Agricultura, Pecuária e Abastecimento, 1956. 
Superstições e costumes. Rio de Janeiro: Editora Antunes, 1958.

CAVITIONE E SILVA, Fabio. Composição da comunidade de aves em área urbana no sul do Brasil. Neotropical Biology and Conservation. São Leopoldo, v. 9, n. 2, 78-90, 2014.

CLARK, Willene Buckman. Birds, Exotic. In: FRIEDMAN, John; FIGG, Kristen (ed.). Trade, travel, and exploration in the Middle Ages, an Encyclopedia. New York: Routledge, 2000. p. 63-64.

A medieval book of beasts: the second-family bestiary. Boydell Press: Woodbridge, 2006.

CLARKE, Tim H. The Rhinoceros from Dürer to Stubbs, 1515-1799. London: Sotheby's Publications, 1986.

COHEN, Simona. Animals as disguised symbols in Renaissance art. Leiden: Brill, 2008.

COLLAR, Nigel James. Family Psittacidae. In: DEL HOYO, Josep; ELLIOTT, Andrew; SARGATAL, Jordi (ed.), Handbook of the birds of the World. Barcelona: Lynx Edicions, 1997. Vol. 4, Sandgrouse to cuckoos, p. 280-477.

COOPER, Thomas. The statutes at large of South Carolina. Columbia: A.S. Johnston, 1837. Vol. 2, Acts from 1682 to 1716 inclusive.

COSTA, Abel Fontoura da. Deambulações da ganda de Modafar, Rei de Cambaia, de 1514 a 1516. Lisboa: Agência Geral das Colónias, 1937.

COURTNEY Julia; JAMES, Paula. The role of the parrot in selected texts from Ovid to Jean Rhys. Lewinston: Edwin Mellen Press, 2006.

CRUZ FILHO, José da. Historia do Ceará: resumo didactico. São Paulo: Editora Melhoramentos, 1931.

DABENNE, Roberto. ¿Los loros deben ser considerados plaga nacional? Hornero. Buenos Aires, v. 6, n. 1, p. 59-63, 1935.

DALTON, Heather. A Sulphur-crested Cockatoo in fifteenth-century Mantua: rethinking symbols of sanctity and patterns of trade. Renaissance Studies. Oxford, v. 28, n. 5, p. 676-694, 2013.

DAVIS, Lewis R. The monk parakeet: a potential threat to agriculture. In: VERTEBRATE PEST CONFERENCE, 6, 1974, Anaheim. Proceedings ... Sacramento: California Vertebrate Pest Committee, 1974. p. 253-256.

DESNOYERS, Jules. Recherches sur la coutume d'exorciser et d'excommunier les insectes et autres animaux nuisibles a l'agriculture. Paris: Imprimerie Impériale, 1853.

DICKENSON, Victoria. Meticulous depiction: animals in art, 1400-1600. In: BOEHRER, Bruce (ed.). A cultural history of animals in the Renaissance. Oxford: Berg, 2007, p. 165-199.

EISLER, Colin Tobias. Dürer's animals. Washington: Smithsonian Institution Press, 1991. 
ELIAS Donald; VALENCIA, Danilo. La agricultura latinoamericana y los vertebrados plaga. Interciencia. Caracas, v. 9, p. 223-229, 1984.

EMERSON, Kathryn Linnemann. The writer's guide to everyday life in Renaissance England. Cincinnati: Writer's Digest Book, 1996.

EVANS, Edwad Payson. The criminal prosecution and capital punishment of animals. London: William Heinemann, 1906.

FARIA, Oswaldo Lamartine de; AZEVEDO, Guilherme de. Vocabulário do criatório norteriograndense. Rio de Janeiro: Ministério da Agricultura, Serviço de Informação Agrícola, 1966.

FONTANA, Carla Suertegaray; BENCKE, Glayson Ariel; REIS, Roberto Esser dos. Livro vermelho da fauna ameaçada de extinção no Rio Grande do Sul. Porto Alegre: Editora da Pontifícia Universidade Católica do Rio Grande do Sul, 2003.

FORSHAW, Joseph Michael. Parrots of the world. Melbourne: Lansdonne Editions, 1978.

FRADE, Fernando. Comentário zoológico relativo à História dos Animais e Árvores do Maranhão (1625-1631) de Frei Cristóvão de Lisboa, II - Aves. Garcia de Orta, Série Zoologia. Lisboa, v. 11, n. 1/2, p. 5-20, 1984.

GOELDI, Emílio Augusto. As aves do Brasil. Rio de Janeiro: Livraria Classica de Alves, 1894.

GONZÁLEZ, José Antonio. Analisis preliminar de los daños causados por las aves silvestres a la agricultura en la Amazonia oriental de Perú. In: Congreso Internacional sobre manejo de fauna silvestre en la Amazonía y Latinoamérica, 5, 2001. Cartagena. Seleción de trabajos... . Bogotá: CITES \& Fundación Natura, 2001. p. 370-380.

GORGAS, Michael. Animal trade between India and western Eurasia in the sixteenth century - the role of the Fuggers in animal trading. In: MATHEW, Kuzhippalli Skaria (ed.). IndoPortuguese trade and the Fuggers of Germany: sixteenth century. New Delhi: Manohar Publishers, 1997, p. 195-225.

GORGAS, Michael; SCHWEINBERGER, Willy. Tiere, Kaiser, Anekdoten. Von Fuggers Maenagerie zum Großstadtzoo. Gersthofen: Vindelica-Verlag, 1986.

GRAZIO, John W. de. World bird damage problems. In: Vertebrate Pest Conference, 8, 1978, Sacramento. Proceedings ... Davis: University of California, 1978. p. 9-24.

GRIGSON, Caroline. Menagerie: the history of exotic animals in England 1100 - 1837. Oxford: Oxford University Press, 2016.

GRINDOL, Diane; ROUDYBUSH, Tom. Teaching your bird to talk. Hoboken: Wiley Publishing, 2004.

HÖFLING, Elizabeth; CAMARgo, Helio Ferraz de Almeida. Aves no Campus da Cidade Universitária Armando de Salles Oliveira. São Paulo: Universidade de São Paulo, 1993.

HOWE, William Norton, 1912. Animal life in Italian painting. London: George Allen. 
HUME, Julian; WALTERS, Michael. Extinct birds. London: T \& Ad Poyser, 2012.

IHERING, Hermann von. As aves do Estado do Rio Grande do Sul. In: AZAMBUJA, G.A. de (org.), Annuario do Estado do Rio Grande do Sul para o anno de 1900. Porto Alegre: Gundlach \& Krahe, 1899, p. 113-154.

JACOBY, Meinhard. A saúva, uma inteligência nociva. Rio de Janeiro: Ministério da Agricultura, 1946.

JENNINSON, George. Animals for show and pleasure in ancient Rome. Manchester: Manchester University Press, 1937.

JIMÉNEZ, Carlos Gómez-Centurión. Virtuosos e impertinentes: los pájaros de cámara en la corte española del siglo XVIII. Bulletin for Spanish and Portuguese Historical Studies. New York, v. 35, n. 1, p. 87-122, 2011.

JOHNSON, Paul Christopher. An Atlantic genealogy of "spirit possession". Comparative Studies in Society and History. Cambridge, v. 53, n. 2, p. 393-425, 2011.

KALOF, Linda. Looking at animals in human history. London: Reaktion Books, 2007.

KARSTEN, Rafael. The civilization of the South American indians. New York: Alfred A. Knopf, 1926.

KELLENBENZ, Hermann. Die Fugger in Spanien und Portugal bis 1560. Ein Großunternebmen des 16. Jabrhunderts. Munich: Ernst Vögel, 1990.

KINIGHT, Maxwell. Talking birds. London: G. Bell \& Sons, 1961.

LACH, Donald Frederick. Asia in the making of Europe. Chicago: University of Chicago Press, 1970. Vol. 2: The Century of Wonder, Book one: The Visual Arts.

LENKO, Karol; PAPAVERO, Nelson. Insetos no folclore. São Paulo: Conselho Estadual de Artes e Ciências Humanas, 1979.

LOISEL, Gustave Antoine Armand. Histoire des ménageries de l'Antiquité à nous jours. Paris: Octave Doin \& Henri Laurens, 1912.

MACMUNN, Meradith T. Parrots and poets in Late Medieval Literature. Anthrozoös. Davis, v. 12, n. 2, p. 68-75, 1999.

MANGIN, Arthur. L'homme et la bête. Paris: Firmin Didot, 1872.

MARCHINI, Silvio; FERRAZ, Katia Maria Paschoaletto Miccchi Barros. Bichos da ESALQ: quais são, como vivem e como lidar com os animais silvestres no campus. Piracicaba: Escola Superior de Agricultura Luiz de Queiróz, 2014.

MEADOW, Mark A. Merchants and Marvels: Hans Jacob Fugger and the origins of the Wunderkammer. In: SMITH, Pamela; FINDLEN, Paula (ed.). Merchants $\mathcal{E}$ Marvels: Commerce, Science, and Art in Early Modern Europe. New York: Routledge, 2002. p. 182-200. 
MELLO E SOUZA, Laura de. O diabo e a Terra de Santa Cruz: feitiçaria e religiosidade popular no Brasil colonial. São Paulo: Companhia das Letras, 1986.

MÉNABRÉA, Léon. De l'origine de la forme et de l'espirit des jugements rendus au Moyen-Age contre les animaux. Mémoires de la Société Royale Académique de Savoie. Chambéry, v. 12, p. 399-523, 1846.

MENAULT, Ernest. L'intelligence des animaux. Paris: Hachette, 1868.

MOROZOV, Vladimir P. A linguagem dos animais. Moscou: Editora Mir, 1983.

MURPHY, Simon (ed.). Cox's fragmenta: an historical miscellany. Stroud: The History Press, 2010.

NOBLE, Bonnie Jeanne. The kind of Virgin that keeps a parrot: identity, nature, and myth in a painting by Hans Baldung Grien. Journal of Literature and Art Studies. New York, v. 4, n 9, p. 702-721, 2014.

NYNAULD, Jean de. De la lycanthropie, transformation et extase des sorciers. Paris: Jean Millot, 1615.

O'DONOGHUE, Denis. Lives and legends of Saint Brendan the voyager. Dublin: Browne \& Nolan, 1893

OJASTI, Juhani. Utilización de la fauna silveste en América Latina. Roma: FAO, 1993.

O'MEARA, Jonh Joseph. The voyage of Saint Brendan: journey to the Promised Land. Dublin: Dolmen Press, 1976.

OREN, David. As aves maranhenses do manuscrito (1625-1631) de Frei Cristóvão de Lisboa. Ararajuba. Rio de Janeiro, v. 1, p. 43-56, 1990.

PAPAVERO, Nelson; TEIXEIRA, Dante Martins. Frei Cristóvão de Lisboa not the author of "História dos animais e árvores do Maranhão". I. Introduction and comments on plates 1-60. Contribuições Avulsas sobre a História Natural do Brasil (Série História da História Natural). Seropédica, n. 6, p. 1-12, 1999.

. Frei Cristóvão de Lisboa not the author of "História dos animais e árvores do Maranhão". II. Further evidence and comments on plates 62-109. Contribuições Avulsas sobre a História Natural do Brasil (Série História da História Natural), Seropédica, n. 28, p. 1-10, 2000.

PEPPERBERG, Irene Maxine. The Alex studies. Harvard: Harvard University Press, 1999.

PÉREZ, Sandra Saenz-Lopez. Um cuento árabe para la imagen del Sultán de Babilonia em lar cartas náuticas mallorquinas. In: CARRIL, Valerià Paül; DONADA, Joan Tort. (ed.), Territorios, Paisajes y lugares. Trabajos recientes de pensamiento geográfico. Cabrera del Mar: Galerada \& Asociación de Geógrafos Españoles, 2007, p. 313-326.

POLLARD, John. Birds in Greek life and mith. London: Thames and Hudson, 1977. 
POND, Caroline. The scientific background to parrots in literature. In: COURTNEY Julia; JAMES, Paula. (ed.). The role of the parrot in selected texts from Ovid to Jean Rhys. Lewinston: Edwin Mellen Press, 2006, p. 175-209.

RAMOS, Graciliano. Histórias de Alexandre. Rio de Janeiro: Leitura, 1944.

RENDON, José Arouche de Toledo. Reflexões sobre o estado em que se acha a agricultura na capitania de S. Paulo. Documentos Interessantes para a Historia e Costumes de S. Paulo. São Paulo, v. 44, p. 195-213, 1915.

ROBBINS, Louise E. Elephant slaves and pampered parrots: exotic animals in eighteenthcentury Paris. Baltimore: Fohns Hopkins University Press, 2002.

SABATIER, Paul. Life of St. Francis of Assisi. New York: Charles Scribner's Sons, 1897.

SACCO, Anne Gomes; BERGMANN, Fabiane Borba; RUI, Ana Maria. Assembleia de aves na área urbana do município de Pelotas, Rio Grande do Sul, Brasil. Biota Neotropical. São Paulo, v. 13, n. 2 , p. 153-162, 2013.

SÁEZ, Adrián. El "divino don de la habla": el Coloquio de los perros desde la tradición clásica y bíblica (contribución al estudio de sus fuentes). In: STROSETZKI, Christoph (ed.), Visiones y revisiones cervantinas. Alcalá de Henares: Centro de Estudios Cervantinos, 2011, p. 797-806.

SANCEAU, Elaine. Capitães do Brasil. Porto: Livraria Civilização Editora, 1956.

SANTOS, Eurico. Da ema ao beija-flor. Rio de Janeiro: F. Briguiet, 1952. Histórias, lendas e folclore de nossos bichos. Rio de Janeiro: Edições “O Cruzeiro”, 1957.

SAXTON, Matthew. Child language: acquisition and development. London: Sage Publications, 2010.

SICK, Helmut. Ornitologia brasileira, uma introdução. Brasília: Editora Universidade de Brasília, 1985.

SIMONSEN, Roberto Cochrane. Historia Econômica do Brasil 1500-1820. São Paulo: Companhia Editora Nacional, 1937.

SNYDER, Noel. The Carolina Parakeet: Glimpses of a Vanished Bird. Princeton: Princeton University Press, 2004.

STEELE, Richard. Advertisement. In: THE SPECTATOR, WITH SKETCHES OF THE LIVES OF THE AUTHORS AND EXPLANTORY NOTES. Edimburgh: Bell \& Bradfute, 1816. Vol. I, p 160-161.

STREHLOW, Harro. Zoological Gardens of Western Europe. In: KISLING Jr., Vernon (ed.), Zoo and Aquarium History. Boca Raton: CRC Press, 2001. p. 75-116.

STRESEMANN, Erwin. Die Entwicklung der Ornithologie: von Aristoteles bis zur Gegenwart. Berlin: F.W. Peters, 1951. 
TEIXEIRA, Dante Martins (org.). Brasil Holandês: Miscellanea Cleyeri, Libri Principis \& Theatrum rerum naturalium Brasiliae. Rio de Janeiro: Editora Index, 1995.

Psitácidas como pragas para a agricultura no Brasil Colônia. Historia Naturalis. Seropédica, v. 1, p. 311-313, 1998.

O mito da natureza intocada: as aves do Brasil Holandês (1624 - 1654) como exemplo para a história recente da fauna do Novo Mundo. Rio de Janeiro: Tese (Doutorado) - PósGraduação em Ciências Biológicas/ Zoologia, Museu Nacional, Universidade Federal do Rio de Janeiro, 1999.

Le commerce d'animaux dans le Brésil coloniale. In: STOLS, E. (org.). Terra Brasilis. Bruxelles: Europalia \& Ludion, 2011, p. 68-85.

; PAPAVERO, Nelson. Os Animais do Descobrimento: a fauna brasileira mencionada nos documentos relativos à viagem de Pedro Álvares Cabral (1500-1501). Publicações Avulsas do Museu Nacional. Rio de Janeiro, v. 111, p. 1-133, 2006.

O tráfico de primatas brasileiros nos séculos XVI e XVII. In: PESSÔA, Leila Maria; TAVARES, William Corrêa; SICILIANO, Salvatore (org.), Mamíferos de Restingas e Manguezais do Brasil. Rio de Janeiro: Sociedade Brasileira de Mastozoologia \& Museu Nacional - UFRJ, 2010, p. 253-282.

THOMAS, Keith. Religion and the decline of magic: studies in popular beliefs in sixteenth and seventeenth century England. Oxford: Oxford University Press, 1971.

TOYNBEE, Jocelyn Mary Catherine. Animals in Roman life and art. London: Thames \& Hudson, 1973.

VASCONCELLOS, José Leite de. Etnografia portuguesa: tentame de sistematização. Lisboa: Imprensa Nacional, 1980.

VERDI, Richard. The parrot in art: from Dürer to Elizabeth Butterworth. London: Scala Publishers, 2007.

WALKER-MEIKLE, Kathleen. Medieval pets. Woodbridge: Boydell Press, 2014.

WEBER AM BACH, Sibylle. Hans Baldung Grien (1484/85-1545): Marienbilder in der Reformation. Regensburg: Schnell \& Steiner, 2006.

WOOD, John George. Man and beast here and hereafter. New York: Harper \& Brothers, 1875.

WOODWORTH, Francis Channing. Stories about birds, with pictures to match. Boston: Phillips, Sampson \& Co., 1851.

YAPP, William Brunsdon. The Illustrations of birds in the Vatican manuscript of De arte venandi cum avibus of Frererick II. Annals of Science. London, v. 40, n. 6, p. 597-634, 1983.

Artigo apresentado em 12/10/2016. Aprovado em 20/02/2017. 